\title{
Implementing Treaty Settlements via \\ Indigenous Institutions: Social Justice and \\ Detribalization in New Zealand
}

Marilyn E Lashley

In New Zealand as well as Australia, Canada, and the United States, the legacy of dispossession and marginalization contributes to ongoing problems of racial and ethnic economic inequality and concentrated chronic poverty. Despite more than twenty years of landmark treaty policy providing indigenous New Zealanders social justice and economic redress, the majority of Maori households still have incomes well below the national and subgroup medians. Although New Zealand has implemented some of the world's most progressive, sustained, and successful policies for rendering reparative justice, treaty settlement has reduced neither income inequality nor the disparate rate of Maori poverty. Treaty settlement as reparative justice successfully provides collective redress to tribal entities that prove wrongful confiscation of tangible assets, such as land, fisheries, forests, and treasures. Yet treaty settlement as reparative justice provides neither adequate nor sufficient redress to most Maori individuals or households harmed by marginalization and the lingering legacy of dispossession. Thus reparative treaty settlement in the absence of distributive instruments, namely targeted policy, is insufficient for remedying the intertwined problems of economic inequality and chronic poverty, particularly when national governments also undertake economic restructuring and public sector reform.

Since signing the Treaty of Waitangi with the British in I840, Maori people have experienced ongoing dispossession and marginalization-the systematic denial of full access to rights and benefits of citizenship by either or both economic and political discrimination against indigenous and other minorities (Gurr and Scarrit 1989). In the twentieth century, the post-World War II economic boom not only fueled further alienation

The Contemporary Pacific, Volume I2, Number I, Spring 2000, I-55

(C) 2000 by University of Hawai'i Press 
of Maori lands but also stimulated and accelerated urban migration, urbanization, and detribalization (the breakdown of Maori culture by weakening kinship links, Maori language use, and tribal customs and practices). Marginalization not only engenders breakdown of the requisite values for acquiring human and physical capital, but when coupled with detribalization also severs access to treaty settlement assets and, thereby, social justice.

The fundamental proposition here is that all Maori are harmed by the legacy of dispossession and marginalization and, thereby, all Maori are entitled to social justice. The central question is what policies should government decision makers implement to render social justice to historically marginalized groups. Here, my focus is not on theories of social justice; rather, it is on the public policies implemented to render social justice and restore equality after acknowledging breached rights. Finding mutually satisfying answers to this question is essential not only for providing redress to historically marginalized groups but also for governance and for remedying racial and ethnic economic inequality and chronic poverty. However, both the role of the state and policy mechanisms for providing social justice remain highly contested, if not contentious, questions among policymakers, voting majorities, and marginalized groups.

Generally policymakers pursue social justice as reparative or distributive policies that seek to ameliorate the grievances of harmed groups yet insure minimal economic, political, and social costs to voting majorities. Reparative justice seeks to restore harmed parties to the position they would have held in the absence of the wrongful act(s), whereby the notion of unjust enrichment governs the nature and amount of reparations or compensatory damages (Miller I99I). Reparative justice is most often (and most narrowly) applied to breached rights to property caused by dispossession. On the other hand, distributive justice seeks to allocate public honors, wealth, or other rewards and penalties of society on the basis of either merit and desert or need and equality. Distributive justice presumes equality of opportunity and that each person's social position and material rewards correspond as far as possible to merit (talents and efforts). Distributive justice is applied to problems of economic need or equality of opportunity and often employs instruments of positive discrimination as targeted policies to improve the relative economic and social position of a specific group or groups within a society. Targeted policies provide material uplift and increased opportunities to offset the 
harm of previous discrimination or need and, thereby, move society toward equality.

Here, I examine both reparative justice as treaty settlement and distributive justice as targeted social policy to provide social justice and analyze the redistributive impact on Maori well-being. In addition to the Treaty of Waitangi and the Treaty of Waitangi Acts, I briefly describe the late I960s pantribal protest movement as well as the government's policy response, claims of breached treaty rights and treaty settlements, and the problem of detribalization. The causes and outcomes of devolution and mainstreaming Maori programs under economic restructuring and public sector reforms - "the New Zealand Experiment"- are also identified. In order to ascertain the redistributive impact on Maori economic and social well-being, I analyze descriptive statistics of the entire population to compare aggregate-level changes in incomes, labor-force participation, and benefit receipt (in the United States, income transfers or "welfare" payments) across population subgroups from I976 to I998. Government and other archival documents are examined and primary and secondary sources are analyzed in order to describe the historical context and identify relevant social policy issues, initiatives, and outcomes. More than one hundred interviews were conducted with ministers of Parliament serving on the Maori Affairs Select Committee, government officials and staff, policy analysts, academics, and business, church, and community leaders.

\section{The Treaty of Waitangi}

On 6 February I 840 New Zealand was established as a British colony through treaty cession achieved by means of the unilateral actions and declarations of William Hobson, lieutenant-governor of the British settlements. The treaty was written in English and Maori. Forty-six Maori chiefs signed a Maori language translation of the treaty at Waitangi, which subsequently was taken around New Zealand and signed by approximately five hundred additional Maori tribal representatives. The core provisions of the treaty are embodied in three articles:

\section{Article I}

The Chiefs of the Confederation of the United Tribes of New Zealand, and the separate and independent Chiefs who have not become members of the Confederation, cede to Her Majesty the Queen of England, absolutely and 
without reservation, all rights and powers of sovereignty which the said Confederation or individual Chiefs respectively exercise or possess, or may be supposed to exercise or possess, over their respective Territories as the sole sovereigns thereof. (English text)

The Chiefs of the Confederation, and all the Chiefs who have not joined that Confederation give absolutely to the Queen of England forever the complete government over their land. (English translation of Maori text; Kawharu I989)

\section{Article II}

Her Majesty the Queen of England confirms and guarantees to the Chiefs and Tribes of New Zealand and to the respective families and individuals thereof the full and exclusive and undisturbed possession of their Lands and Estates Forests Fisheries and other properties which they may collectively or individually possess so long as it is their wish and desire to retain the same in their possession; but the Chiefs of the United Tribes and the individual Chiefs yield to Her Majesty the exclusive right of Preemption over such lands as the proprietors thereof may be disposed to alienate at such prices as may be agreed upon between the respective Proprietors and persons appointed by Her Majesty to treat with them in that behalf. (English text)

The Queen of England agrees to protect the chiefs, the subtribes and all the people of New Zealand in the unqualified exercise of their chieftainship over all their lands over their villages and over all their treasures. But on the other hand the Chiefs of the Confederation and all the Chiefs will sell land to the Queen at a price agreed to by the person owning it and by the person buying it (the later being) appointed by the Queen as her purchase agent. (English translation of Maori text)

Article III

In consideration thereof Her Majesty the Queen of England extends to the Natives of New Zealand Her royal protection and imparts to them all the Rights and Privileges of British Subjects. (English text and English translation of Maori text)

Maori people understood the Treaty of Waitangi as a power sharing and governance contract between two parties, Maori people and the Crown, whereby Maori people are equal parties with the British in the cultural, social, economic, and political life of New Zealand (Kingi I994; Henare I994). However, the English and Maori texts of the treaty differ profoundly. According to the English text, indigenous Maori ceded "all the rights and powers of sovereignty over their respective territories" to 
Queen Victoria. Maori people retained "full exclusive and undisturbed possession of their lands and estates, forests, fisheries and other properties" (Article II) in return for "royal protection" and "all the rights and privileges of British subjects" (Article III). According to the Maori text, Maori ceded kawanatanga (governance) not sovereignty and retained rangatiratanga (chieftainship). For Maori, this distinction is paramount. The fundamental difference between the two texts, from the Maori perspective, is that confirmation of chieftainship also confirms sovereignty, in return for a "limited concession of power."

\section{Context of Contemporary Maori Protest and Policy Advocacy}

Despite the treaty's guarantees, and equivalent status conferred as signatory party, the early experiences of Maori under British colonization were marred by wars over land settlement and sovereignty, abrogated treaty rights, and land confiscation and alienation. Historically, Maori political and economic position and interests were subordinate and marginal to the interests of Europeans. ${ }^{1}$ Even though twentieth-century policymakers pursued policies of racial assimilation by encouraging racial intermarriage from the I940s through the I960s, the dominant ethos-the dream of one people-was not achieved. In the watershed report by the Department of Maori Affairs on 24 August 1960, then Acting Secretary for Maori Affairs J K Hunn identified significant disparities between Maori and Europeans in income, housing, and education. The report also showed Maori landholdings substantially diminished under the 1953 Maori Affairs and the Town and Country Planning Acts. ${ }^{2}$ In 1960 there were 3, I68 land leases covering 466,194 acres, and by 1965 the number of leases had increased to $3,48 \mathrm{I}$ covering $6 \mathrm{I} 8,580$ acres; in the same period land sales escalated from 5,245 to 5 I,824 acres (Schwimmer I968, 24). By 1990 government-sanctioned land alienation had reduced Maori landholding to only 5 percent of 60 million acres.

Therefore, the 1967 Maori Affairs Bill, which further undermined tribal ownership, was the shot heard throughout Maoridom that galvanized pantribal opposition and opened the door for the 1975 Treaty of Waitangi Act. This bill amended the I953 Maori Affairs Act to render it less harmful to Maori while maintaining compulsory sale to Europeans of land held by multiple Maori owners. Maori opposition to the bill was led and guided by Matiu Rata (1934-1997), Labour member of Parliament 
for Northern Maori (1963-1980) and minister of Maori Affairs and minister of Lands (1972-1975). Prodded by Rata, Parliament amended the proposed bill, giving Maori incorporations greater consultation and rights of appeal, and the options to trade shares and retain unclaimed dividends (Maori Affairs Amendment Act 1967). However, the enacted legislation continued the compulsory sale of Maori incorporation land, but on the basis of having "ceased to be Maori land" instead of having been "declared European land" (Hazelhurst 1993, 46). Thus the I967 Maori Affairs Amendment Act ignited Maori protest. Maori leaders not only opposed it, but accused the National party government of being openly hostile to Maori interests and urged Maori from all tribes to actively protest against the inequities in New Zealand society. Although united in opposition to further alienation of Maori land and inequality, Maori were divided on remedies and protest strategies. The Act stimulated sharp debate among Maori leadership that pitted more conservative elders against younger advocates, who demanded redress of Maori grievances.

In 1968, young, urban-based, and largely university-educated Maori formed the pantribal organization, Nga Tamatoa (the Young Warriors) to draw attention to the Treaty of Waitangi and demand both restoration of tribal lands and redress of grievances common to all tribes (Kingi 1994; Te Hemara 1994). Nga Tamatoa took a militant stance in advocating the use of Maori language as an official language, return of illegally confiscated lands, settlement of treaty breaches, and recognition of Maori rights as one of the two signatory parties to the Treaty of Waitangi, the founding document of the New Zealand state. Nga Tamatoa redefined Maori identity by drawing on the movements for US Civil Rights, American Indians, and women, as well as black power ideology, and attributed the marginal and unequal status of Maori to institutionalized white racism and oppression (Henare 1994; Walker I995). ${ }^{3}$ Most notably, and to the chagrin of many, in I97I Nga Tamatoa declared 6 February (New Zealand's national day commemorating the signing of the Treaty of Waitangi) the national "day of mourning for the loss of Maori land" and staged dramatic protests to publicize the plight of Maori. Even today Maori activists still capture official New Zealand Day ceremonies, held annually at Waitangi on 6 February, to call attention to Maori grievances.

By the I970s the older generation of Maori leaders had also become more activist in advocating the return of Maori land and Maori rights as indigenous people and treaty party. Most prominently, Dame Whina Cooper (I 895-I994), one of Maoridom's most distinguished and 
respected elders and former president of the Maori Women's Welfare League, at eighty years old led the historic 1975 Maori Land March from Auckland to Wellington. Both the Land March and the 1977 Bastion Point Protest and subsequent occupation were pantribal protests organized by Nga Tamatoa in conjunction with established Maori organizations representing a wide spectrum of opinions on Maori issues. Resurgence of Maori protest and demands for redress, equity, and social justice also led some Maori leaders to espouse separatism and absolute Maori sovereignty. ${ }^{4}$ Although many white New Zealanders dismiss Maori demands for sovereignty, restoration of te tino rangatiratanga, as absurdly radical or merely rhetoric, as did distinguished treaty scholar Paul McHugh (I99I, 49), some Maori remain quite serious in the demand for Maori self-government. Several Maori activists maintain there is a legal basis for Maori self-government, and some still work toward this end (S Jackson I994; M Jackson I994). However, consensus on an operative definition of sovereignty has not been reached, and Maori demands range from Maori self-government, to separate Maori development, to a separate system of justice for Maori (parallel legal system).

\section{The Government's Response: Reparative and} Distributive Policies

In response to heightened Maori activism in the I960s and I970s, the Treaty of Waitangi was placed at the center of New Zealand governance and policymaking. In 1975 Parliament enacted the Treaty of Waitangi Act-legislation crafted and shepherded to passage by Matiu Rata. The rule of contra preferentum was invoked, which holds that where a divergence or ambiguity in a treaty document between two parties results, a provision should be construed against that party which drafted the document (Kingi 1984). The New Zealand Government accepted the tenets of international law: "each of the parties to a treaty drawn up in two languages has the right to rely on its own version for purposes of interpretation, unless there is an express stipulation that only one of the texts shall be authoritative" (Hardy I961). The I975 Treaty of Waitangi Act reasserted the importance of the Treaty of Waitangi as the founding document of New Zealand. This act created a standing tribunal to hear claims of breached treaty rights, investigate all new legislation from 1976 onward for possible treaty breaches by determining "the meaning and effect of the Treaty of Waitangi as embodied in the two texts [English and 
Maori], and to decide issues raised by the differences between them" (Treaty of Waitangi Act 1975 \$5[2]). ${ }^{5}$ The 1975 act established the Waitangi Tribunal as a division within the Department of Justice consisting of a chairperson (chief judge of the Maori Land Court) and up to sixteen appointed members, and staffed by civil servants.

In 1985, the Labour government of Prime Minister David Lange (1984-1989) amended the 1975 Treaty of Waitangi Act and greatly enlarged its scope. The 1985 Treaty of Waitangi Amendment Act increased the Waitangi Tribunal from three to seven members, with four seats reserved for Maori, and made its jurisdiction retroactive to 6 February 1840 , the date of treaty cession. In 1988 , tribunal membership was increased to seventeen, including the chief judge of the Maori Land Court, and the majority Maori membership requirement was removed. In 1995, the Office of Treaty Settlements (отs) replaced the Treaty of Waitangi Policy Unit (which facilitated claims research and processing) and was mandated to negotiate and implement treaty settlements. According to Edward T Durie, then chief judge of the Waitangi Tribunal, "the Tribunal's main function is to inquire into and make recommendations to the Crown upon claims submitted to it by Maori” (I996). The tribunal makes findings that are not legally binding (with four exclusions) and may make proposals for long term restoration but cannot recommend return of land. The tribunal functions as a commission of inquiry, is not a court, and is not bound by rules of evidence.

\section{Treaty Settlement and Social Justice}

Claims of breached treaty rights were filed almost before the ink was dry on the Treaty of Waitangi. Although treaty-based appeals were made to the Crown by Maori chiefs as early as I 847 , the landmark settlements are due to the Treaty of Waitangi Act of 1975 and Treaty of Waitangi Amendment Act of 1985. The Treaty of Waitangi is a legal obligation between individual iwi and hapu (tribes and subtribes) and the Crown. Claims are filed under Article II for wrongful alienation of collectively held (tribal) private assets, specifically, land, fisheries, forests, and other treasures. In general, claimants seek public acknowledgment by the Crown for wrongdoing, restoration of sovereignty over sacred sites, and redress (compensation) for the illegal confiscation of private assets (or their restoration). According to Minister of Justice and Minister in Charge of Treaty of Waitangi Negotiations Doug Graham, the treaty settlements process is not 
intended to adjudicate matters of social justice or equity but to provide fair compensation for lands, fisheries, forests, and other tangible assets unjustly confiscated by the Crown. "Any or all Maori can bring a claim against the Treaty of Waitangi but they must demonstrate prior ownership of tangible assets" (Graham I994).

On the question of Maori sovereignty, in a 23 November 1994 interview, Minister Graham maintained that indigenous Maori ceded all the rights and powers of sovereignty over their respective territories to Queen Victoria and retained "full, exclusive and undisturbed possession of their lands and estates, forests, fisheries and other properties," in return for "royal protection" and "all the rights and privileges of British subjects" (Treaty of Waitangi, Articles I-III). In the minister's view, problems of racial and ethnic equality are "issues of economic and social justice and are covered under Article III. As British subjects and New Zealand citizens, Maori have the same rights as everybody else and deserve no special treatment" (Graham 1994). However, at a legal conference on Io February 1995, and after unsettling demonstrations by "radical Maori" that disrupted Waitangi Day ceremonies, Minister Graham "took the surprising step of saying New Zealand should be looking at the issue of sovereignty or self-determination for Maori, an issue he had described ten days before as irrelevant to the settlement package" (Gardner I995, 2).

\section{Claims of Breached Treaty Rights}

Iwi-Based Claims. The government has pursued settlement of both iwibased (tribal) claims and complex claims on behalf of and affecting all Maori (pantribal claims). Given the Treaty of Waitangi's status as the founding document of New Zealand that stipulates obligations between individual iwi (tribes) and the Crown, treaty settlements are provided as direct redress by means of tribal mechanisms-Maori culture. Therefore, treaty settlements are negotiated and implemented by individual iwi. Treaty settlements are collectively held tribal assets that are administered by individual iwi. Tribal trust boards maintain official registers of iwi ancestry, kinship networks, and membership. Assets and benefits from treaty settlement are best accessed by individuals through active iwi membership, active affiliation, and strong attachment to Maori culture through the marae. The marae is the cornerstone of Maori culture and provides spiritual, economic, social, and political organization as well as a literally sacred tribal meeting house. When and where treaty settlements (and other targeted policies, such as affirmative action, biculturalism, language 
preschools, and economic development initiatives) have been most effective and successful, they have been implemented and accessed by means of the marae structure as iwi-sponsored activities. For example, the Tainui Trust Board and the Ngai Tahu Trust Board use the marae to provide community-based educational, social, and health services and employment training to tribe members.

Old, Gifted, Crown Purchase, and Confiscation Claims. To some extent, both the ability to prove unencumbered ownership of tangible assets and the ability to exact settlements are products of historical accident because they also turn on the process by which land and other assets were alienated and the level of acceptance by particular $i w i$ in partnership with the Crown. In the main, land was alienated by means of purchase, gifting, and confiscation. Consequently, it is possible to file several types of claims of breached treaty rights: as old, gifted, crown purchase (pre and post I 865), or confiscation (raupatu) claims. Old claims are filed for land alienated prior to British sovereignty (NZOTS 1996). Raupatu claims are filed for land wrongfully confiscated as punishment of Maori tribes who rebelled. Gifted claims are filed for land made available for "temporary purchase," to be returned when the original purchasers left, died, or no longer used it for the purposes of the original gift.

However, particular types of claims are proving much more difficult for some Maori tribes to litigate and settle successfully. Raupatu claims are less complicated than gifted or pre-I 865 purchase claims because the land in question was confiscated directly by the Crown. For example, descendants of the Waikato tribes (which historically asserted their own sovereignty, opposed the Crown, and refused to accept the treaty) reached a deed of settlement on their raupatu claims in May 1995, while negotiations continue on the Crown purchase claims. The descendants of tribes that accepted treaty partnership, had their lands alienated by means of Crown purchase or gifting, and migrated to urban areas early on, also tended to abandon their tribal ties. For example, the Muriwhenua and Ngati Whatua tribes filed main claims on the validity of pre-I 840 purchases (old land claims) and smaller raupatu claims. Given the preponderance of old claims and the extent of assimilation with white settlers, Muriwhenua and Ngati Whatua encountered greater burdens of proof and greater difficulty in achieving a tribal mandate and representation consensus (Goodall 1997). Because Muriwhenua and Ngati Whatua tribes exercised extensive contact and amicable relations with settlers and Crown officials, they also experienced greater land loss and detribaliza- 
tion than more rebellious tribes-which some Maori maintain was the price paid for partnership.

Pantribal Claims. In addition to claims filed on behalf of specific tribes, several "pantribal" claims have been filed on behalf of "all Maori." For example, the Te Reo Maori Claim (Maori language claim) is a pantribal claim filed with the tribunal on 3 May I984. In its 29 April 1986 report, the tribunal recommended enactment of legislation obligating the government to use Maori language in all official business and to promote and enable use of Maori language nationwide. Another pantribal claim, brought by the Wellington Maori Language Board in June I990, challenged the attempted sale of frequency-management licenses under the Radio Communications Act I989 (privatization of the public broadcasting system). Although the tribunal completed hearings and issued an initial report on 6 June 1990 and the Radio Spectrum Management and Development Interim Report on 26 March 1999, the "Broadcasting Claim" remains unsettled. Another active claim, filed on 9 October I99 I on behalf of te iwi Maori (the Maori people) and still before the tribunal, seeks to protect the use of indigenous flora and fauna, cultural and intellectual property, and base resources from exploitation (eg, bioprospecting and bio-engineering genetic materials). "Claims of these types account for about one-third of all claims brought to hearing before the Waitangi Tribunal, and an even larger number of similar claims are dealt with before the Planning Tribunal and, more recently, the Environment Court. Some serious judgements on the same issues have been obtained from the High Court and Court of Appeal" (Goodall 1997).

\section{Adjudicated Claims}

By October 1998, 745 claims had been filed under the 1985 Treaty of Waitangi Amendment Act. More than 254 claims have been adjudicated (settled, dismissed, or withdrawn). ${ }^{6}$ Of the adjudicated claims, settlements of most significant and most substantial economic development benefit are the pantribal commercial fisheries claim (also known as the Sealords Deal) and separate sets of claims by the Tainui tribes and by the Ngai Tahu tribes. The fisheries claim was settled in September 1992 and established the Treaty of Waitangi Fisheries Commission. The initial fisheries settlement provided a fishing quota of 30 percent and NZ\$ 50 million to promote Maori commercial fishing and to establish ten tribally owned companies, including Sealord Products Limited and Moana Pacific Fisheries. However, the schedule for asset distribution among tribal groups 
has been besieged by legal challenges. A deed of settlement was reached with the Tainui tribe in May I995, and provided compensation of NZ\$I 70 million, a public apology to Waikato Maori from the Queen (Crown), the return of $\mathrm{I} 4, \mathrm{I} 64$ hectares of land valued at NZ\$I $\$$ o million, and a NZ\$65 million trust fund.

The Ngai Tahu filed the other major and significant set of claims in 1986. This set of claims is perhaps the most complex, because it involves almost the entire South Island and sweeps nine major and diverse claims under one umbrella. ${ }^{7}$ Although the Waitangi Tribunal ruled Ngai Tahu claims valid and recommended settlement in I99I, a heads of agreement only was reached on 5 October 1996 and a deed of settlement was signed on 2I November 1997. Although the current value of the assets appropriated from the Ngai Tahu is estimated at more than NZ\$2O billion, the terms of settlement provide, foremost, a formal public apology by the Crown and a redress package. Redress includes but is not limited to NZ\$I70 million plus interest, which can be used to purchase Crownowned assets. The package also transfers ownership of Crown-owned pounamu (greenstone) land, restores ownership and title to Mount Aoraki (Mount "Cook," which Ngai Tahu will gift back to the nation), provides up to $\mathrm{NZ} \$ 2.5$ million to settle more than thirty small ancillary land claims, and restores other assets including reserves, mabinga kai (food resources), and forests (NTNG I997).

Another important deed of settlement under negotiation addresses claims by the Whakatohea tribes. Heads of agreement and deed of settlement were reached in these claims. However, in July I997 the deed of settlement, which included a public apology and NZ\$4O million, was rejected by the Whakatohea tribal council, principally because it required the extinction of all aboriginal rights and all future claims, not exclusively the raupatu (confiscated land) claims. More important, rejection of the Whakatohea claim by tribal membership signaled that the negotiators lacked both a tribal mandate and sufficient tribal support for the terms of settlement.

The tribunal has rendered only one binding recommendation. In the Turangi Township claim, the tribunal recommended both the return of land transferred by the Crown to state-owned enterprises and monetary compensation. In 1995, the tribunal reported that the claim brought by the Ngati Turangitukua was well founded and breached several principles of the treaty. These included the Crown's compulsory acquisition of 
claimants' land when a suitable site owned by the Crown and available for the purpose existed nearby; failure to adequately compensate the Ngati Turangitukua for their loss; and failure to return land acquired for an industrial area as promised (Waitangi Tribunal I998a, 2). In an earlier report (1996), the tribunal had recommended that the Crown and claimants negotiate settlement. After two years of negotiations, the parties sought a binding recommendation from the tribunal. In the following report released on 8 July I998, the tribunal made the binding recommendation that some of the Crown-owned confiscated land be returned, and that the Crown make monetary compensation to the claimants.

However, the most prominent pantribal claim is the "fisheries claim." Although settlement on this claim was reached in September 1992 (Waitangi Tribunal I992b), and the Treaty of Waitangi Fisheries Commission identified a schedule for distributing settlement assets to tribes, disbursement is impeded by litigation. In separate actions, several Maori organizations challenged the model proposed by the Fisheries Commission to allocate and redistribute presettlement assets. Thus far the challenges have generated three significant appeals to the Privy Council concerning the interpretation of the term iwi and the statutory duties of the Treaty of Waitangi Fisheries Commission in the allocation and distribution of settlement assets.

In I994, wearied of the political and economic costs of the tribunal process and treaty settlements, the National government of Prime Minister Jim Bolger proposed a full, final, and permanent settlement within a prescribed period in the amount of NZ\$I billion total compensation for all outstanding claims - the Crown Settlement Proposals, also known as "the fiscal envelope." Beginning on 2 February 1995, a series of thirteen regional meetings, hui, were convened by the minister in charge of Treaty of Waitangi negotiations, Minister of Justice Doug Graham, and other government officials to present the Crown Settlement Proposals, describe the process of implementation, and address questions. In bui after bui, Maori people resoundingly and with mounting outrage rejected the fiscal envelope. After the conclusion of the 25 March 1995 hui at Christchurch, Minister Graham canceled the remaining hui scheduled for Porirua, Wellington. The government refused to amend the proposals but signaled its intention to salvage the plan. Treaty negotiations continued amidst protest, while Prime Minister Bolger, Justice Minister Graham, and officers and staff of the Ministry of Maori Development lost considerable face. 


\section{Social Justice as Targeted Social Policy}

As they initiated reparative treaty settlement policies to provide redress, government decision makers simultaneously introduced policies of positive discrimination targeted toward Maori development and material uplift. Although Parliament had earlier established the Department of Maori Affairs (DMA), and later the Maori Education Foundation (I96I), to address the unique social and educational needs of the Maori, in the I980s the government expanded Maori Affairs programs to include economic, education, health, and social service initiatives. The government formulated an array of policies to address Maori grievances and mandated implementation and administration to the Department of Maori Affairs. For example, in I98I the department introduced the first of several education programs to revitalize Maori language, kohanga reo (language nests). In October 1984, Minister of Maori Affairs Koro Wetere (1984-1990) convened the Maori Economic Development Summit Conference in Wellington, bringing Maori leaders and activists together with government officials to identify Maori social and economic needs and consider proposals for improving Maori well-being. The three-volume proceedings document formed the basis for developing targeted programs, subsequently adopted by the Department of Maori Affairs, and launched the "Development Decade" (I984-I994). The department implemented several new initiatives by contracting directly with Maori organizations and enterprises to deliver programs and services to Maori people. Most notably, these included economic development and employment training programs such as Mana Enterprises (I986) and Maori ACCESs (1987). The department also implemented a major health initiative to improve Maori physical well-being and life expectancy by lowering rates of mortality associated with poverty, limited information, and access to services and treatment. Equally important, the budget authority for Maori affairs was increased substantially, from NZ\$67 million to NZ\$250 million in I985, in order to carry out these policies (Gardiner I994).

The government also enacted policies of biculturalism and affirmative action that respectively buttressed and complemented the efforts of the Department of Maori Affairs. In 1984, the Labour government of Prime Minister David Lange implemented biculturalism to provide Maori greater inclusion in New Zealand society and to affirm and recognize the special relationship between Maori and Pakeha as the two parties to the Treaty of Waitangi. Biculturalism acknowledges the existence of both of 
these ethnic groups as founders of the New Zealand state with particular and distinctive claims as New Zealanders (NZMMD 1986). As the signatories to the Treaty of Waitangi, Maori and Pakeha have inherited moral, political, and social obligations that require them to negotiate a relationship that is equitable for both-a partnership. In 1985, policymakers enacted the Law Commission Act, which proclaimed a new national ethos for New Zealand-as a bicultural nation and multicultural society. Later that year, the Department of Social Welfare (DSw) established the Ministerial Advisory Committee for a Maori Perspective to investigate and identify the most effective approach to meet the needs of Maori people in policy, planning, and social service delivery; the outcome was the pivotal document, Puao-te-Atatu/Day Break (NZDSw I986).

In 1987, the Race Relations Conciliator introduced a comprehensive system of affirmative actions "to improve the collective welfare of the community by the just distribution of success and status according to the situation faced by different groups" (RRC I987, 90). Like its American prototype, the system was formulated to address the unique circumstances and social and economic needs of Maori people as marginalized citizens in order to attain equality of results, and affirmative action was extended to employment, economic development, and higher education. In the 1988 State Sector Act, government departments were further mandated to establish equal employment opportunity programs and publish program plans annually. Although the State Sector Act sought equality of outcomes, quotas and other numerical requirements were excluded.

\section{Collision of Social Justice with Economic Restructuring and Public Sector Reform}

In the I980s, New Zealand policymakers enacted macroeconomic policies to restructure an ailing economy that collided with social justice policies enacted to settle Maori grievances. Prime Minister David Lange not only implemented sweeping public sector reforms aimed at devolving government and stabilizing the economy, but also simultaneously amended the Treaty of Waitangi Act and greatly enlarged its scope. The 1985 Treaty of Waitangi Amendment Act produced a profusion of claims of breached treaty rights, while the hundred-year-old Department of Maori Affairs was eliminated.

In order to reverse the New Zealand economy's downward spiral, from I 984 to 1994 successive Labour party and National party governments- 
the "new Right"-enacted radical economic and social policy reforms that departed sharply from the long-established tradition of democratic socialism. Upon assuming office in 1984, Labour Prime Minister David Lange confronted a monetary crisis compounded by enormous budget deficits and massive deindustrialization. Conservative fiscal and monetary policies initiated in 1984 by the Labour government's minister of finance, Roger Douglas, were continued and extended by the National Party from I990. By July I994 Prime Minister Jim Bolger (I990-I997) announced that the National government had achieved a fiscal surplus, increased economic growth three years running (by 4.6 percent in I994), lowered inflation to under 2 percent, and was expected to reduce net public debt by nearly half of gross domestic product in 1997 (down from 60 percent to 30 percent).

Highly acclaimed by the International Monetary Fund, the New Zealand Experiment accomplished a budgetary and social policy revolution. Foremost, import controls and tariffs were removed to stimulate and stabilize economic growth, and private and public sector employment was deregulated. The 1987 Labour Relations and State Sector Acts profoundly altered employee-employer relations by limiting union organizing, and the 199I Employment Contracts Act abolished compulsory union participation, effectively reorganizing work-primarily into sets of part-time jobs at lower pay, with greatly abridged employee rights and without health or other fringe benefits. On the fiscal side, the government introduced a Io percent goods and services tax in October 1986 (raised to I 2.5 percent in June 1989), increased indirect taxes, and substantially reduced personal tax rates for medium-to-high wage earners. The government also authorized the sale of state-owned enterprises and other government assets, instituted user fees for government services previously provided free of charge, and assessed market rates for state (public) housing, which further reduced the disposable incomes of lower-income persons. Universal medical coverage was eliminated, and medical care to the uninsured and low-income groups was rationed, while hospitals were consolidated or closed. In short, government departments and activities were eliminated, downsized, or reorganized.

\section{Shifting Maori from Targeted to Universal Programs}

Devolution. Prime Minister Lange's program of devolution included phased-out elimination of the Department of Maori Affairs in 1985 (effective I October 1989). The language of "devolution" was not only used to 
transfer power, resources, and responsibility to subnational or local-level government agencies, but "devolution" also restructured the "partnership" between Maori people and the government of New Zealand. In I989, the Department of Maori Affairs was replaced by the Ministry of Maori Affairs and the Iwi Transition Agency (Ministry of Maori Affairs Restructuring Act 1989). The Ministry of Maori Affairs provided policy planning to the Iwi Transition Agency. Maori affairs were devolved to the Iwi Transition Agency, which was established to acknowledge the enduring traditional significance of $i w i$; identify the characteristics by which $i w i$ are to be recognized; provide for the incorporation of runanga (Maori councils, literally tribal collectives) to represent $i w i$; provide a process for the resolution of conflicts between $i w i$; and provide registration of $i w i$ by any iwi of a body corporate as the authorized voice of the iwi (Runanga Iwi Act I990, 2). The Runanga Iwi Act created a subnational governance structure headed by a chief executive (general manager) that linked the state to tribal entities and used Maori input and expertise to provide community-based programs and social services. The Iwi Transition Agency contracted directly with iwi and other Maori tribal organizations to deliver economic development programs and social services to Maori locally.

Both the elimination of the Department of Maori Affairs and the establishment of the Iwi Transition Agency met with strident opposition from many Maori and further divided Maori leadership on the basis of tribal or nontribal approaches to Maori development. Most prominently, then National Party Minister of Maori Affairs and Minister in Charge of the Iwi Transition Agency Winston Peters (I990-I992), promised to repeal the Runanga Iwi Act. Although this act represented greatly improved relations and commitment by the state, it negated Maori rangatiratanga (chieftainship) and made iwi subordinate to the state (Cox I993; McLeay I99I; McHugh I99I). Passage of the Runanga Iwi Act in I990 and two related bills - the Local Government Amendment Act (also known as Bill No. 8, which charged runanga of each region to elect members to form Maori Advisory Committees) and the Resource Management Act-formalized and established a government-recognized system of Maori political organizations based on traditional tribal structures (iwi). Passage of these bills also marked the state's abandonment of its heretofore "handsoff policy" that contributed to and fanned pan-Maori activism on treaty and other grievances and, thereby, effectively dampened the impact of pantribal organizations (eg, Nga Tamatoa) and neutralized the pan-Maori movement (McLeay I99I). 
Opponents argued that these bills undermined the equal parties concept inherent in the treaty by relegating Maori to a subordinate role in policy decision making. In particular, Bill No. 8 failed to recognize that $i w i$ are, in their own right, autonomous, legitimate jurisdictional and constitutional authorities and effectively "replace[d] the constitutional relationship of equality between Iwi and Crown, provided for in the Treaty, with a relationship where the Iwi are subordinate and merely consulted" (ITA I990, 37). The very definition and meaning of treaty partnership were challenged and reinterpreted in the ensuing debate on these bills: Was the treaty between the Crown and Maori people as a whole or between the Crown and local tribes and extended familial groupings? Furthermore, the debate prompted Maori to demand a voice in determining Maori policy priorities and remedies-self-determination.

The impact of colonization and later urban migration had transformed, if not destroyed, the fabric of Maori social life and discipline (Metge 1964; I976), and for some the solution to the ensuing problems of alienation, anomie, and inequality rested in Maori self-help implemented by means of kinship groupings (Mahuta 1978). The policy of devolution simultaneously sharpened and elevated this discourse, revealing a Maoridom composed of two communities - those rooted in the traditions of te iwi, and those transformed by cultural assimilation and urbanization. Devolution both stanched the growing conflict between Maori pantribal and tribal organizations over Maori affairs and highlighted differences between their organizational goals, principles, and structures of authority (Sharp I992, 264). However, some Maori leaders viewed devolution and the Runanga Iwi Act as promoting the self-interest of particular Maori elites or as divisive and causing competition among iwi; others regarded these initiatives as opportunities for self-help and tribal uplift (Te Ua I994; Cox I993, I42). In addition to strategic differences, however, this conflict reflected growing class differences that also underpin the detribalization debate and litigation over the distribution of treaty settlement assets.

Mainstreaming. Under Prime Minister Bolger's (1990-I997) National government, and true to Minister Winston Peters' prior pledge, in I99I the Ministry of Maori Affairs and the Iwi Transition Agency were disestablished, and programs previously delivered by these units were transferred to "main stream host agencies." However, Winston Peters was ousted due to differences with the National Party over the goals of Maori policy. Consequently, John Luxton, a Pakeha, succeeded Peters as minister of Maori Affairs (1992-1996) and the Ministry of Maori Develop- 
ment (Te Puni Kokiri-TPK) was established in I992. This new ministry's function was primarily passive, to provide policy advice and "to promote increases in the levels of achievement attained by Maori with respect to education, training and employment, health and economic and resource development; monitor and liaise with each department and agency that provides services to Maori” (Ministry of Maori Development Act I99I, $\$_{5}$; italics in original).

Under mainstreaming, Maori policy was shifted from a two-pronged strategy of social justice requiring both pantribal distributive and tribal reparative mechanisms to a strategy primarily focused on providing reparative justice via iwi-based mechanisms. According to Minister of Justice Doug Graham, the objective was to mainstream Maori into universal programs with the aim of providing social policy to Maori consistent with Article III of the treaty, relating to citizenship benefits and privileges. "Maori were to be treated like every body else" (Graham I994). Hence, targeted social and economic programs administered by Maori Affairs, as related sets of bureaucratically coordinated initiatives, were transferred to government departments.

Equally important, budget authority for targeted policy initiatives and programs previously administered by the Department or Ministry of Maori Affairs was transferred to mainstream host agencies, and staff levels were cut from approximately I, 500 to 304 persons. For example, ministry records show that NZ\$53.9 million allocated to the department for Maori job training under the Maori ACCEss program was shifted to the Ministry of Education in I992 (NZMMD I994). Budget authority for administering the department, which peaked at NZ\$270 million in fiscal year $1989-90$, was reduced to NZ\$36 million in fiscal year I993-94 for the Ministry of Maori Development (Gardiner 1994). The Summary of Mainstreaming shows that more than NZ\$I2I.I million was transferred from eleven TPK programs to other government departments in fiscal year I992-93 (NZMMD 1994). Although this study does not permit analysis of total budget authority shifted from Maori programs to mainstream government departments and agencies, it appears that total funding for Maori programs transferred to the relevant government units exceeded the Department of Maori Affairs' high mark of NZ\$270 million.

In sum, Prime Minister Bolger's mainstreaming policy was, de facto, a retreat from the short-lived centralized coordination and administration of social policy targeted to Maori people initiated under the Labour government. Even former Minister of Finance Ruth Richardson (I990-1994) 
later charged that the dismantling of the Ministry of Maori Affairs effectively substituted the vote for Maori social policy for treaty settlement. Perhaps more important, Maori leaders increasingly deem the Ministry of Maori Development impotent or regard it as self-serving. Sir Peter Tapsell, former member of Parliament (198I-I996) and Speaker of the House of Representatives (I993-I996) acknowledged that abolishing the Department of Maori Affairs had been a mistake. Speaking at a regional seminar in Tauranga, Sir Peter said "Maoris had no faith in Te Puni Kokiri" and called for establishment of a "stand-alone Maori Development Department" (I998).

\section{Impact of the New Zealand Experiment on Maori Social and Economic Well-Being}

Unfortunately, reparative treaty settlements, in the absence of sustained policies of distributive justice, neither narrowed the gap between European and Maori incomes nor offset the harm of marginalization and detribalization. Rather, urban Maori also bear the brunt of deindustrialization, economic restructuring, government downsizing, and public sector reforms. The decade of the New Zealand experiment not only increased income inequality but also reduced Maori well-being. Although changes in Maori well-being are evident in several measures, including crime and incarceration, discussion here is confined to descriptive analyses of changes in income, labor force participation, and benefit receipt (poverty). Data are derived from New Zealand censuses (sNZ I996a, b), and surveys of household labor force, household expenditure and income, and household economics (SNZ I998c, I99I, I998b, respectively). In I 996 the official population of New Zealand was approximately 3.6 million (of whom 72 percent were European, I 4.5 percent Maori, 5 percent Pacific Islanders, and 4 percent $A \operatorname{sian}^{8}$ ) and the labor force exceeded I.8 million persons.

\section{Income}

Personal income from all sources increased for all groups in the wake of the experiment. However, the shift from "cradle to the grave" democratic socialism to free market capitalism lowered real household incomes and increased income inequality. Figure I shows median personal income as a proportion of European income. Maori income fell from 85 percent of European income in 1976 to 73 percent in I99I and rose slightly in 


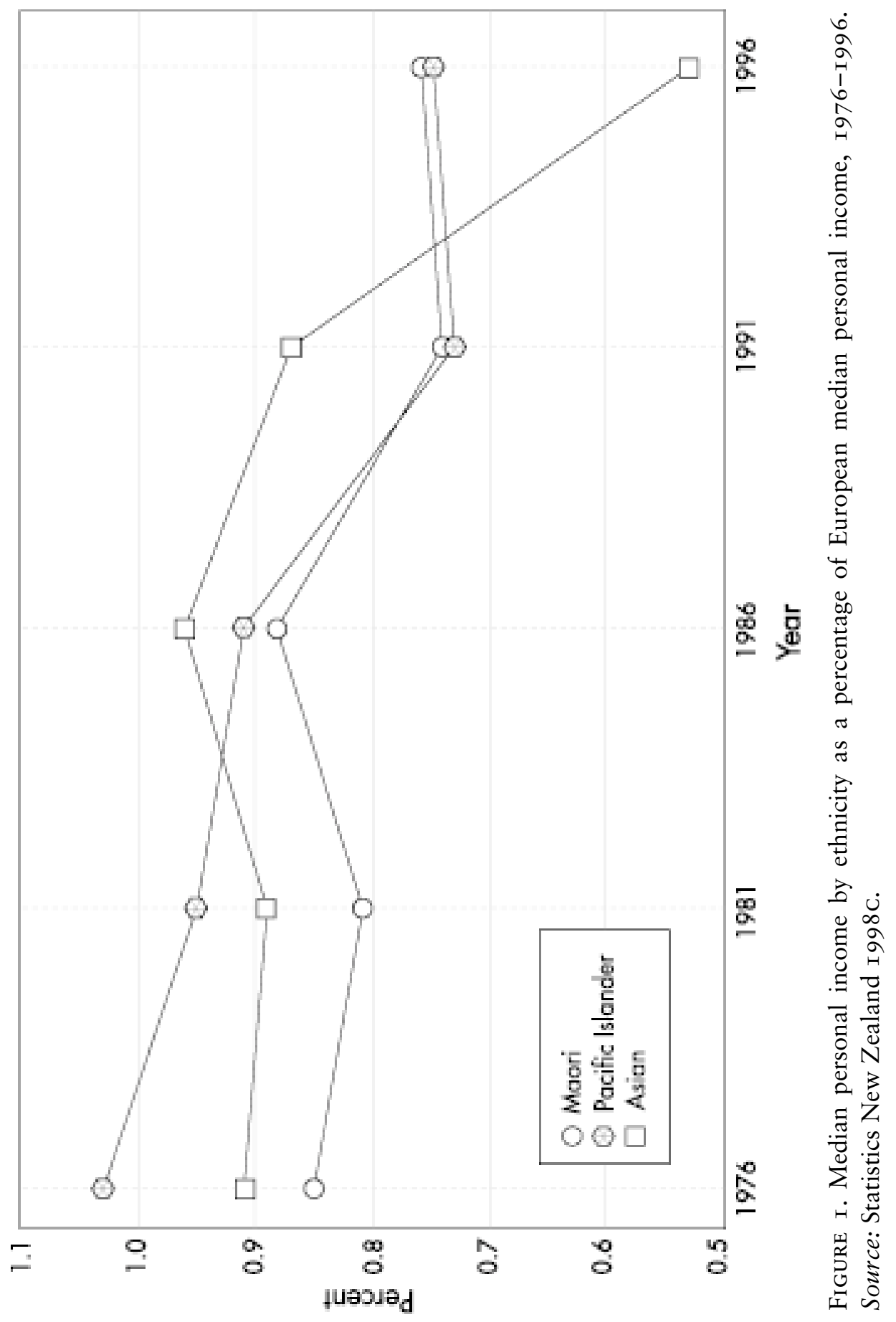


1996. Median personal income for Pacific Islanders exceeded that of all other groups in 1976 but fell to 74 percent of European income by 1996. However, the drop in Asian incomes from 96 percent of European income in I99I to 53 percent in 1996 is most striking. According to Len Cook, government statistician, the decline in Asian median personal income is due largely to intercensal increase in Asian immigration between I986, I99I, and 1996 (personal communication, I 5 Sept 1998). The total Asian population increased by 95 percent in 1986 and nearly 7I percent in 1996. In 1996 the Asian population consisted largely of workers aged I 5-44, with incomes under NZ\$10,000.

Given the wide variation in household composition, I have used data compiled by the Population Studies Centre at the University of Waikato. These data are standardized for family size, composition, and age and adjusted for inflation. They compare changes in the proportion of families in each ethnic group with household incomes from all sources equivalent to those in each quintile for "all families combined" in I98 I, I99I, and 1996 (table I). From I98I to I99 I median family incomes declined for all groups. The proportion of Maori and Pacific Island families in the bottom quintiles increased as Europeans shifted from lower quintiles into higher and top income quintiles. As well, Maori families experienced greater net losses over the decade. In I98 I, 54 percent of Maori and 38 percent of European families were in the two bottom income quintiles, while ro percent of Maori and 2I percent of European families were in the top income quintile. By I99 I the number of Maori families in the bottom quintiles rose to 6I percent, while Maori families in the top quintile declined to 8 percent. However, Europeans fared better, as families in the bottommost quintiles fell to 34 percent, while families in the three highest quintiles increased. In 1996, 6I percent of Maori families still have incomes below the median for Maori, while 56 percent of Pacific Islanders and 34 percent of Europeans had incomes below their respective group medians. Not only are more Maori falling out of the middle and upper income brackets, but the gap between Maori and European family incomes widened from NZ\$I7,05I in I99I to NZ\$20,729 in 1996.

\section{Labor Force Participation}

In order to explain differences in income, I examined the qualitative as well as quantitative character of labor force participation in New Zealand. ${ }^{9}$ The New Zealand labor force comprises all resident persons aged fifteen years and over, who work twenty or more hours per week full or 
Table I. Proportion of Each Ethnic Group with Incomes Equivalent to Income Quintiles for All Families Combined in I98I, I99I and I996. (Percentages)

\begin{tabular}{|c|c|c|c|c|c|c|}
\hline & \multicolumn{5}{|c|}{ Family Income Quintiles } & \multirow{2}{*}{$\begin{array}{l}\text { Median } \\
\text { Family Income* } \\
\qquad(\$)\end{array}$} \\
\hline & Bottom & Fourth & Third & Second & Top & \\
\hline \multicolumn{7}{|l|}{1981} \\
\hline European & 19 & 19 & 20 & 20 & 21 & 48,229 \\
\hline Other & 21 & 20 & 18 & 21 & 21 & 47,133 \\
\hline Maori & 30 & 24 & 19 & 16 & 10 & 36,590 \\
\hline $\begin{array}{c}\text { Pacific Island } \\
\text { All Families }\end{array}$ & 29 & 27 & 19 & 19 & 6 & $\begin{array}{l}35,804 \\
46,809\end{array}$ \\
\hline \multicolumn{7}{|l|}{1991} \\
\hline European & 15 & 19 & 20 & 21 & 24 & 38,458 \\
\hline Other & 22 & 19 & 19 & 19 & 21 & 34,333 \\
\hline Maori & 42 & 19 & 17 & 13 & 8 & 21,407 \\
\hline $\begin{array}{l}\text { Pacific Island } \\
\text { All Families }\end{array}$ & 39 & 24 & 19 & 12 & 6 & $\begin{array}{l}22,106 \\
34,776\end{array}$ \\
\hline \multicolumn{7}{|l|}{1996} \\
\hline European & 15 & 19 & 21 & 22 & 23 & 49,424 \\
\hline Other & 32 & 23 & 16 & 14 & 15 & 32,803 \\
\hline Maori & 39 & 22 & 17 & 14 & 8 & 28,695 \\
\hline $\begin{array}{l}\text { Pacific Island } \\
\text { All Families }\end{array}$ & 32 & 25 & 21 & 15 & 7 & $\begin{array}{l}32,278 \\
41,011\end{array}$ \\
\hline \multicolumn{7}{|c|}{ Percentage Change, 1981-1996 } \\
\hline European & -0.3 & .01 & 0.6 & 0.5 & -0.8 & +2 \\
\hline Other & -11.4 & 4.4 & -3.61 & -4.2 & -6.8 & -44 \\
\hline Maori & -3.3 & 3.0 & -0.3 & 1.0 & -0.4 & -28 \\
\hline $\begin{array}{r}\text { Pacific Island } \\
\text { All Families }\end{array}$ & -6.8 & 1.5 & 1.1 & 3.0 & 1.3 & $\begin{array}{l}-11 \\
-14\end{array}$ \\
\hline
\end{tabular}

Source: Derived from Martin I995, 8, I7; personal communication July I998.

* Income data are standardized for age and household composition and size, and adjusted for inflation in March 1996 New Zealand dollars. 
part time, and includes persons still in school. In I 996 nearly 5 I percent of all workers aged I 5-59 years who were employed full time had eleven years or less education, and 24 percent left school without qualifications. Figure 2 shows that aggregate labor force participation decreased for all groups over the course of the New Zealand experiment. Rates of labor force participation for European males declined, though unevenly, from I 976 to 1993 and rose to 75 percent by I998. Maori males experienced greater decline than all other male groups. Falling labor force participation shifted Maori employment from the highest to the lowest for all groups, from 82 percent in 1976 , to 69 percent in 1994 and 72 percent in 1998. Rates for both Pacific Island and Maori males were roughly equal over the period, falling from 82 percent in 1987 to 72 percent in 1998. In 1976 labor force participation for European males was lower than for Maori males at 73 percent. However, from 1989 to 1998 the rates for European men exceeded those of Maori and Pacific Island males, during and after the reforms, averaging 75 percent. (To some extent, this trend also reflected changes in immigration policy governing guest workers, largely Pacific Islanders, who must have employment in order to reside in New Zealand.)

Labor force participation rates did not increase for all female subgroups over time. Labor force participation was substantially higher for Pacific Island females than for all other female ethnic groups in 1987, at 59 percent, fell to 49 percent in 1993 , and rose to 56 percent in 1998 . Similarly, the rates for Maori females fell from 53 percent in 1987 to 49 percent by 1993, but increased to 56 percent in 1998. Labor force participation rates for European females remained stable over the entire period, averaging 54 percent from 1987 to 1996 and 58 percent thereafter.

Occupations. In years just prior to the reforms, the labor market tended to be unsegmented and the labor force was largely working class. The labor force was dominated by unskilled blue-collar workers concentrated in primary production and agricultural occupations (table 2). Workers shared similar levels of education, and earnings differences were smaller among workers with eleven years or less schooling in 1976 than in later years, or for workers with tertiary or higher education in all years (Lashley 1999,56 ). (Primary production workers enjoyed greater pay parity than workers in other occupations, given stringent union regulation.) Analysis of census data on educational characteristics of the labor force from 1976 to 1996 showed that nearly 77 percent of all full and part time 


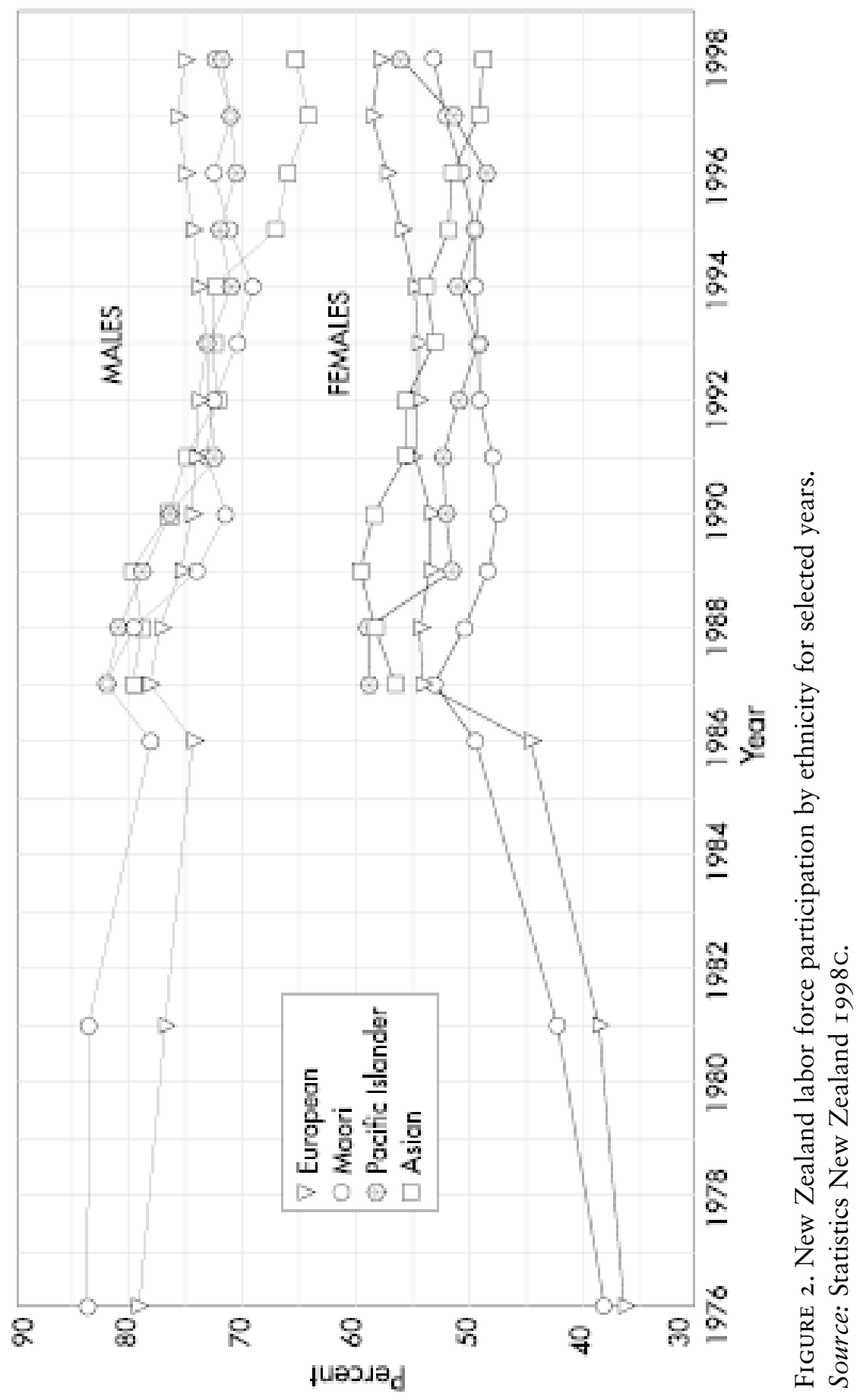




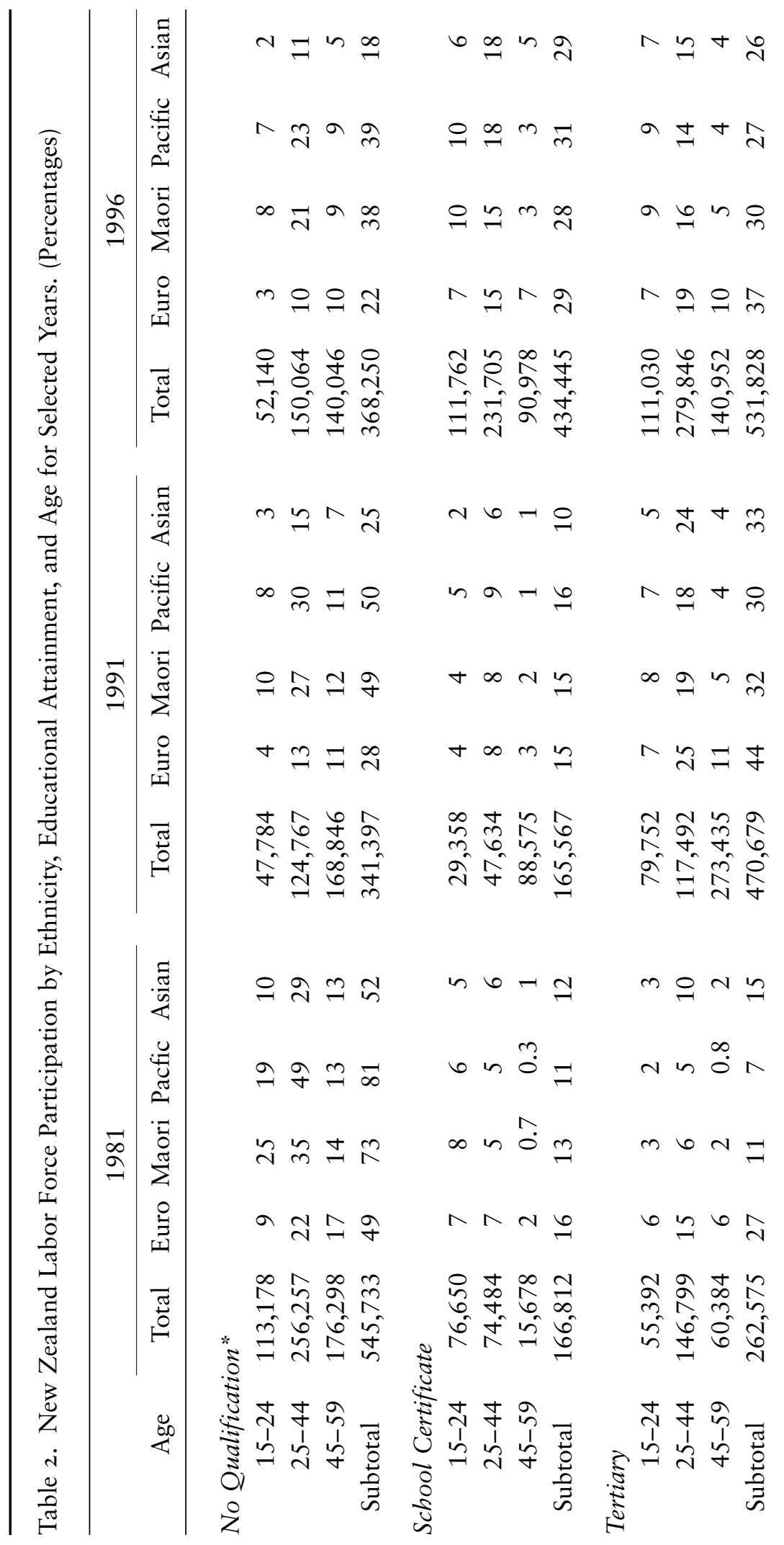




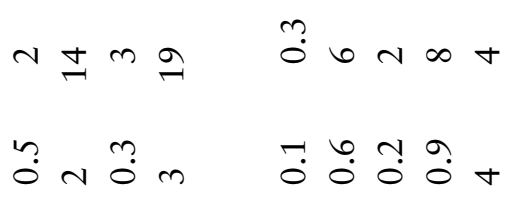

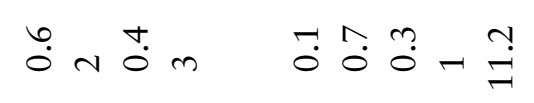

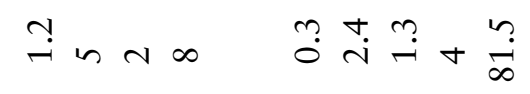

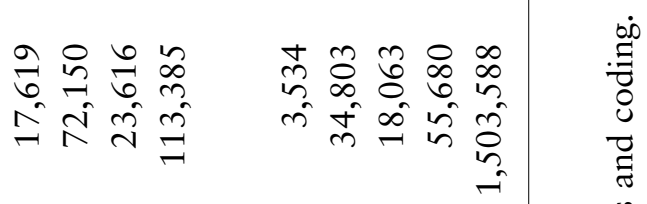

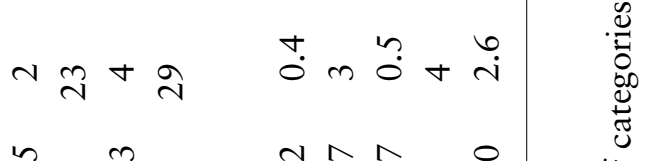

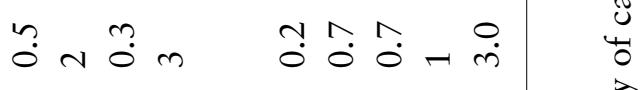

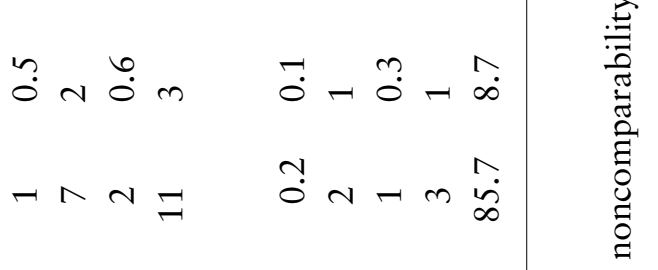

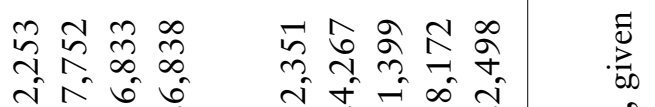

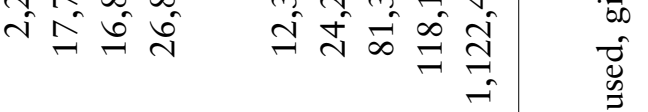

$$
\begin{aligned}
& \text { n }
\end{aligned}
$$

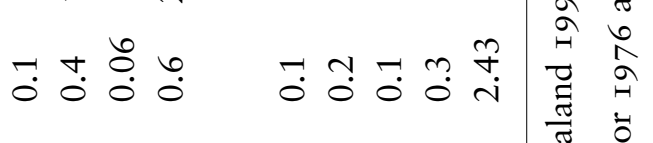

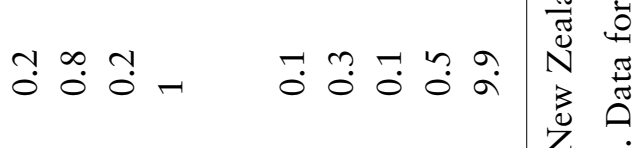

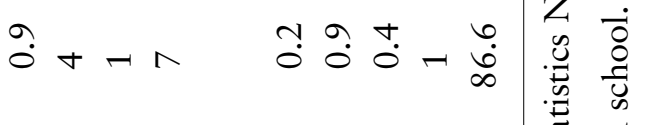

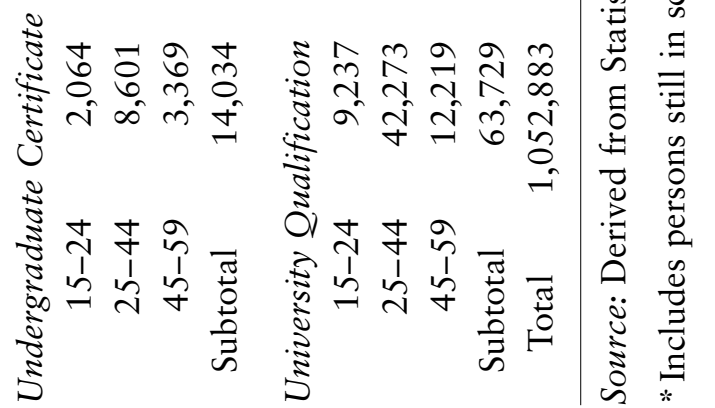


workers had eleven years or less education, and 52 percent left school without qualifications in $198 \mathrm{I} .{ }^{10}$ Workers in all age and ethnic groups vastly improved their levels of educational attainment between I98I and 1996. School leaving without qualifications fell significantly, by 27 percent for Europeans, 35 percent for Maori, 42 percent for Pacific Islanders, and 34 percent for Asians. In 1996, 47 percent of the labor force had eleven and more years schooling-tertiary or higher education.

Table 3 shows that from I97I to I986 more than 72 percent of the entire New Zealand labor force was concentrated in occupations related to agriculture and production. Not only did a preponderance of Maori and Pacific Island workers hold jobs in these occupations, but the majority of European workers in I97I also held unskilled jobs in agriculture (males I4 percent; females 5 percent) and production (males 46 percent; females 17 percent). The total number of male workers in agriculture and production fell to $5 \mathrm{I}$ percent in I99I and to 47 percent by I996, while males in professional and technical occupations doubled, from ro percent in I97I to 20 percent in I996. However, despite vast gains in education, Maori and Pacific Island workers remained concentrated in agriculture and production-related occupations.

Furthermore, Asian immigration and the reforms are transforming the New Zealand labor market. In the 1996 census, New Zealand statisticians discerned rudiments of labor market segmentation. ${ }^{11}$ For the first time in New Zealand history, government statisticians found a "broad occupational split," with European and Asian ethnic groups, excluding Cambodians and Vietnamese, "most likely to work in professional and white collar occupations while people from New Zealand Maori and Pacific Island groups are most likely to work in blue collar and unskilled occupations," primarily as trades workers, plant and machine operators, and assemblers (sNZ 1998a, 7).

Unemployment. Data on unemployment rates are available for all population subgroups only from 1987. In response to shifts in the economy and deindustrialization, total unemployment rose from the low of 4.I percent in I987 to II.I percent in I993 and declined to 6.8 percent by March 1998 (figure 3). Unemployment rose most markedly for Pacific Islanders, from 6 percent in 1987 to the high of 29 percent in 1992, slowing to 25 percent in 1993 , and falling to 15 percent in 1996 and holding. (This drop may be attributed to many Pacific Islanders' status as guest workers who return to their islands of origin after plant closings and job loss.) Following a similar but not identical pattern, unemployment among 


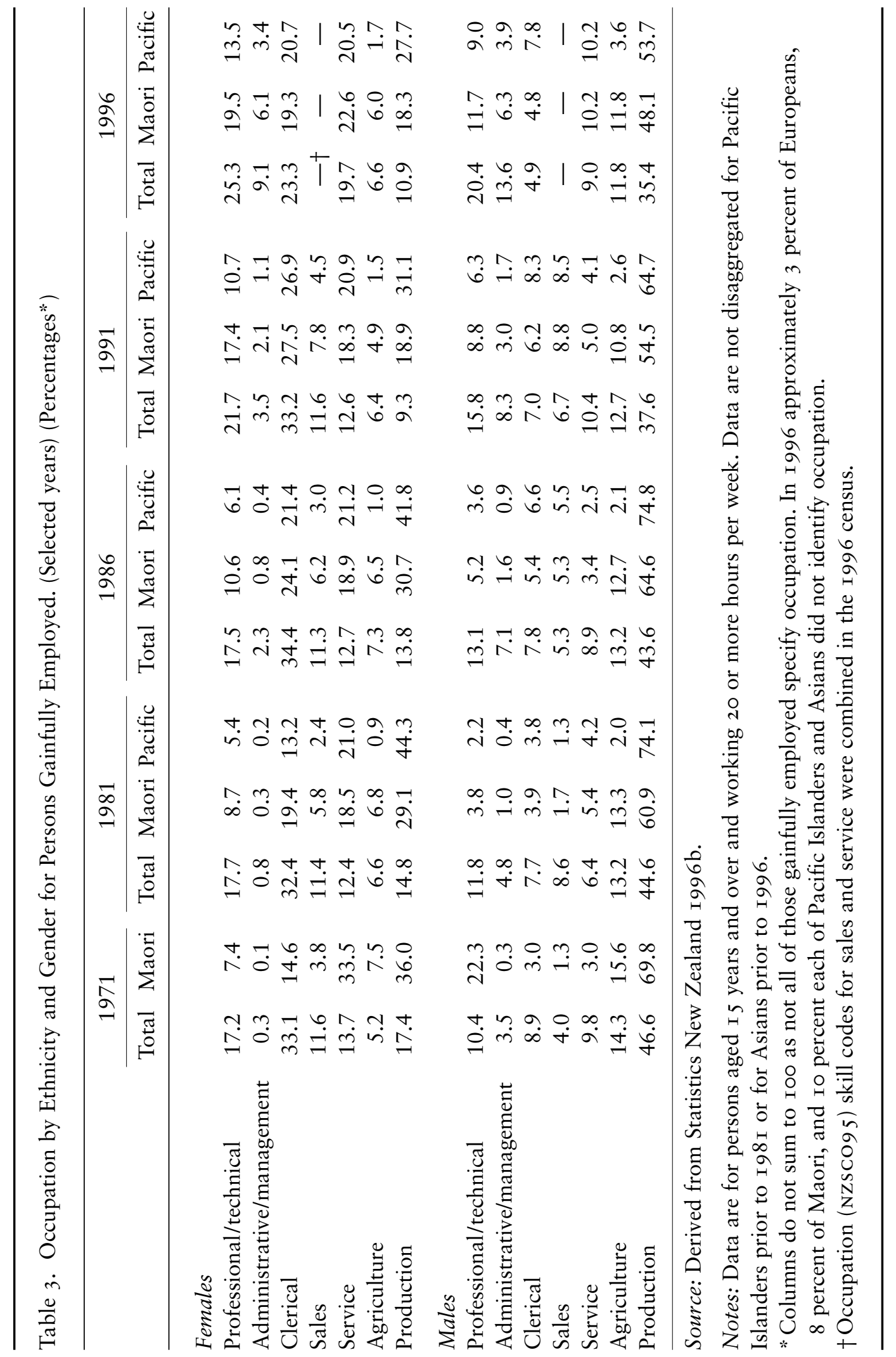


Maori rose from the 1987 low of II percent to a high of 26 percent in I992, gradually fell to I 5 percent by I996, and rose slightly to I 8 percent in 1998. Europeans experienced significantly lower rates of unemployment over the period: 3 percent in $1987,7.9$ percent in 1993 , and an average of 4.4 percent thereafter. Asian unemployment rose over the period, from the lowest for all groups, 4 percent in 1987 , to 13 percent in 1998.

\section{Benefit Receipt}

Collecting data on poverty trends in New Zealand is more nettlesome because the government eschews the logic of an official poverty line and does not release raw census data, which would permit computation of one. Furthermore, the Department of Social Welfare records of benefit receipt and ethnic origin are not maintained consistently over time. When ethnic origin is recorded, applicants are not asked or encouraged to identify race or ethnicity. Instead, racial identification is an item that appears on benefit applications in some years and not in others. When the item appears on applications, response is voluntary. Because the Department of Social Welfare does not maintain reliable or consistent data on benefit receipt by ethnicity, Statistics New Zealand derives these data from responses to "sources of income" questions in the Household Expenditure and Income Survey and in response to question I 4 on the Census of Population and Dwellings: "Which types of income support have you received during the last I 2 months?" Four caveats are important when analyzing the data on benefit receipt:

- The range of benefits and their eligibility criteria have changed over the last decade. For example, the universal family benefit was phased out and replaced by the means tested family support benefit, an income supplementing benefit. The domestic purposes benefit, an income replacement benefit for single parents and older women, was reduced.

- Benefit receipt is subject to over- and under-reporting.

- Respondents may receive several benefits, either sequentially as their situation changes or simultaneously (eg, family support and domestic purposes benefit).

- Some benefits are intended as total replacements for income (domestic purposes and unemployment), while others are supplements to income (family support, youth and student allowances, and emergency assistance). 


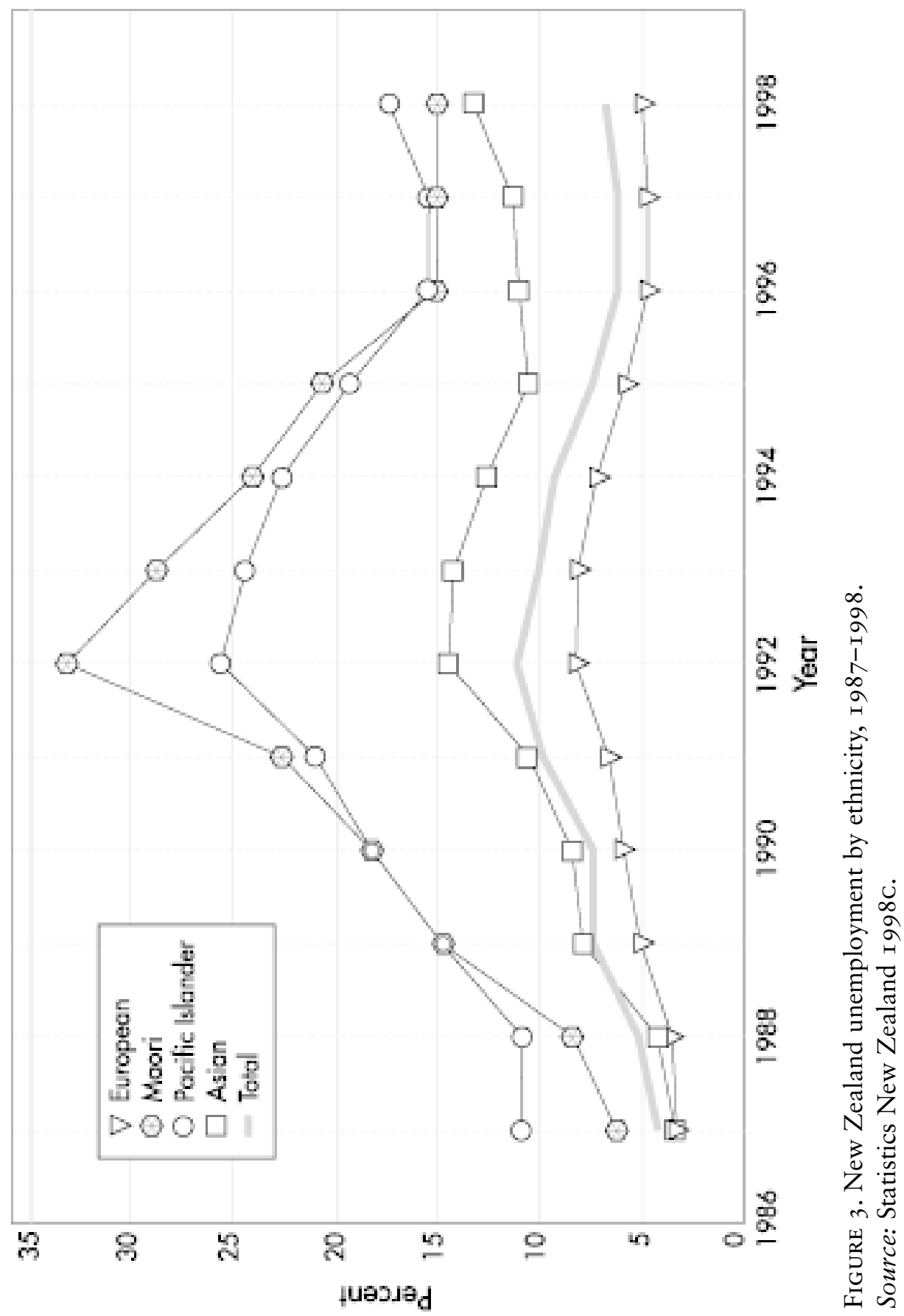


Until 1985 , all benefits were made as income transfer payments under a universal scheme with thirteen categories: widows; orphans; unsupported child; age (until I976); family (abolished I990); domestic purposes (initiated I975); income support; superannuation; unemployment; invalid; sickness; supplementary; and emergency assistance (abolished I974). In I986 nine categories were redefined as means tested on the basis of inadequate income (SPA I993, I2-I3). The need-based income support benefit (which paid NZ\$6,907 for a single adult without dependents and NZ\$ I I, 5 I I for married adults) placed income support recipients (disproportionately more Maori) in the lowest income quintile in 1993. Superannuation is the most generous benefit, paying 80 percent of the gross average wage to married couples and 60 percent to single persons aged 59 and older. In 1986 superannuation averaged annual payments of NZ\$I6,I80 (one person) and NZ\$30,436 (two persons) and placed superannuitants in the second income percentile.

Data show significant changes in benefit receipt over the decade. In figure 4 total benefit receipt for Maori and Europeans was within a single percentage point in I98I (I3.I percent and I2.I percent respectively). Benefit receipt is significantly lower for Pacific Islanders (6.5 percent) than other groups, consistent with macroeconomic trends and immigration policy governing guest workers and immigrants. However, benefit receipt increases and diverges in 1986 , rising to 17 percent for Maori and I 3 percent for Europeans, while falling slightly for the other groups. Despite cuts in welfare spending, and consistent with shifts in the New Zealand economy, total benefit payments to unemployed workers increased by 20 percent between 1989 and 1990. By I991, benefit receipt not only increased among all groups but became more disparate, rising to $\mathrm{I} 5$ percent for Europeans, 3 I percent for Maori, and 23 percent for all others.

When the data for benefit receipt are disaggregated, not only are the expected differences by age, gender, and ethnicity illuminated, but they increase in the wake of the New Zealand experiment. According to the Department of Social Welfare, in I99I, of the 2.5 million persons aged I 5 and over resident in New Zealand, 45 percent received some type of benefit payment; of those, 44 percent were males and 65 percent females. Due to population subgroup differences in age composition and life expectancy, a greater proportion of Maori received income support benefits (40 percent) and far fewer survived to collect superannuation in I992. (Of those aged 60 and older, Europeans make up I7 percent of the population, while Maori consititute only 4 percent.) Of all Maori fami- 


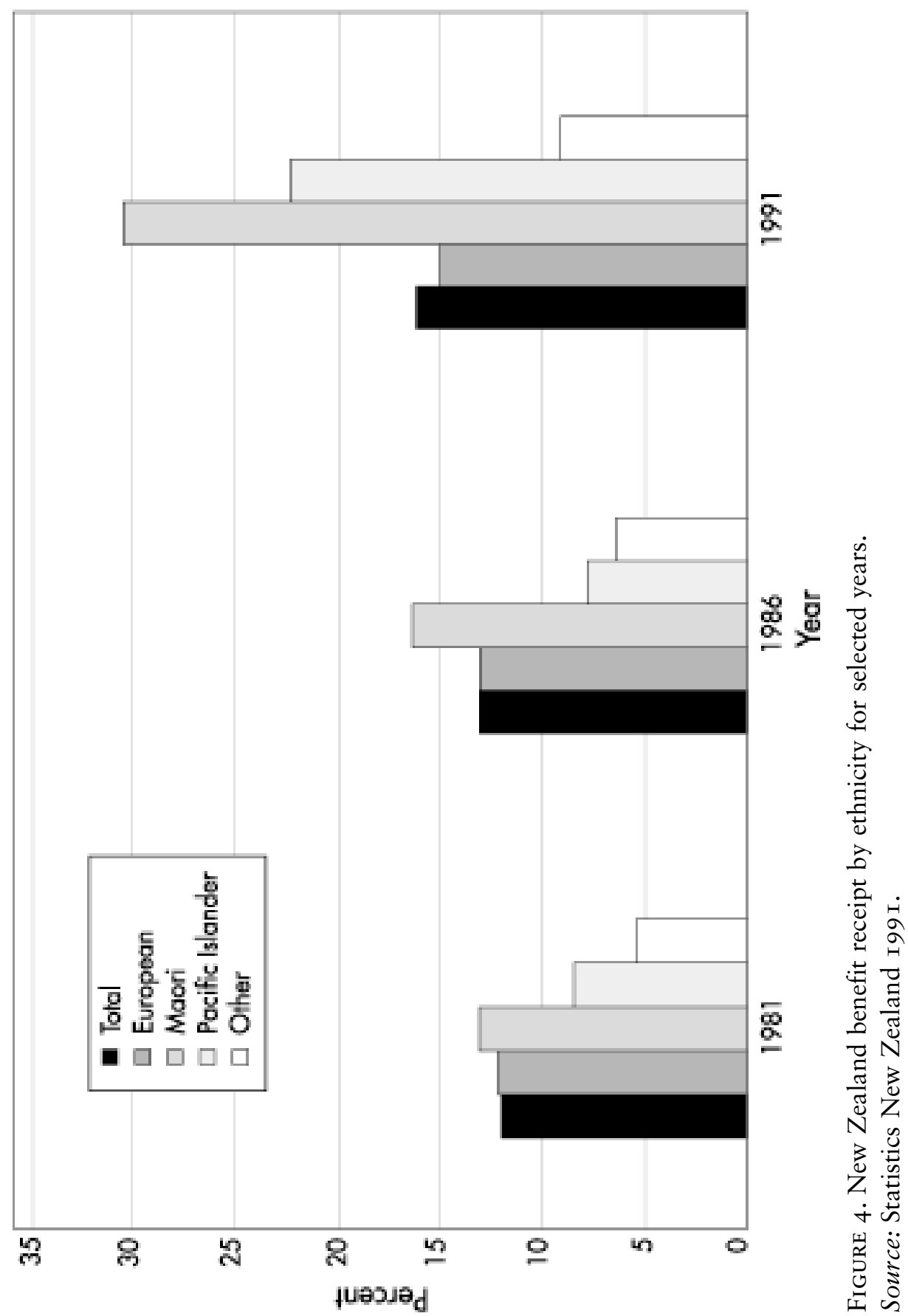


lies with children, 44 percent are single parent families; corresponding figures are 32 percent for Pacific Islanders, and $\mathrm{I} 8$ percent for Europeans. In I994, more than half of total welfare benefits were allocated to superannuation ( 53 percent), while I 5 percent went to unemployment, I 3 percent to domestic purposes, 8 percent to sickness and invalids, and the remaining I I percent to all other categories (NZDSW I994).

Table 4 shows how the composition of benefit receipt changed over the decade. Foremost, the number of persons receiving two or more benefits increased significantly for all groups. Most women receive income support under the family support benefit, and a greater proportion of Maori women are dependent on income support benefits than either Pacific Islanders or Europeans. Similarly, among male recipients, a greater proportion of Maori receive income support than do Pacific Islanders or Europeans. However, Maori males primarily receive income support as unemployment benefits, whereas European males primarily receive family support benefits. This trend may reflect sequential effects of benefit receipt, where more Europeans shift from the unemployment benefit to the family support benefit or shift from unemployment into part-time work at minimum wages in combination with the family support benefit. Moreover, a preponderance of Maori work in seasonal employment, such as sheep shearing and harvesting, which subjects them to spells of employment and cycles of unemployment. Most important, the value of the standard benefit rate declined substantially, from 59 percent in 1976 to 42 percent of weekly average net wages in 1994. In other words, in I994 persons entirely reliant on the standard income support benefit lived on less than half of the gross average wage before taxes-NZ\$238.52. In sum, benefit receipt significantly determines trends in household incomes, especially for Maori and Pacific Islanders.

\section{The Limits of Treaty Settlement and the Problem of Detribalization}

Declining real incomes and rising poverty among Maori, concurrent with achieving deeds of settlement with substantial redress packages, have rekindled the debate over the redistribution of treaty settlement assets. Comparative analyses of census data show that Maori constitute a disproportionate share of New Zealand's urban poor. Forty-four percent of Maori are on the "dole" and New Zealand's new "urban underclass" exhibits many of the same characteristics and pathologies as the American 
urban underclass - impoverished minority families concentrated in economically distressed neighborhoods. Most Maori (and Pacific Islanders) reside in urban areas with high rates of poverty, joblessness, teenage pregnancy and out-of-wedlock births, school leaving without certification, and crime. Increasingly, Maori youth are estranged from Maori culture and alienated from New Zealand society. Many Maori (and Pacific Island) youth strongly identify with African American youth and consciously emulate their "black brothers and sisters." Some Maori youth even define their alienation and marginalization in "gangsta rap" and "white racism" terms. More sobering is the increased despair among Maori (and Pacific Island) youth reflected by growing crime, violence, school leaving, chronic drug use (largely glue sniffing), and suicide.

Unfortunately, the economic benefits from treaty settlement assets may be beyond the reach of individual Maori and have limited trickle-down capacity for reversing the decline in Maori household incomes and offsetting the pathologies of poverty. Rather, as redress for illegal confiscation of private assets collectively held, treaty settlement assets are not intended for distribution as trickle-down social welfare.

In order to assist impoverished Maori concentrated in distressed urban areas, some Maori have formed urban Maori authorities to provide community-based economic development and social welfare services. ${ }^{12} \mathrm{Te}$ Whanau O Waipareira Trust (the Waipareira Trust), based in West Auckland, and the Manukau Urban Maori Authority Incorporated (MUMA) in South Auckland, are urban Maori authorities that deliver social welfare services to Maori and are funded, in part, by the government via the Community Funding Agency (CFA). This agency is a unit within New Zealand's Social Welfare Agency that contracts with providers to deliver health, employment training, and other social services directly to citizens in their communities. Funding to the agency was reduced substantially during the decade of social welfare and public sector reforms. In turn, funding to urban Maori authorities was also cut, and the Waipareira Trust legally contested the cuts. According to John Tamihere, chief executive officer of the Waipariera Trust, "Maori are 35 percent of the West Auckland population and the Trust is the only Maori provider of services targeted to Maori people in this community. The Trust received I7 percent of total CFA funding allocated to West Auckland in 1992 and only I4 percent in I993" (I994). In an effort to have funding restored, the trust filed with the tribunal a claim of breached treaty rights under Article III. The claim argued that the Waipareira Trust is a treaty partner rep- 


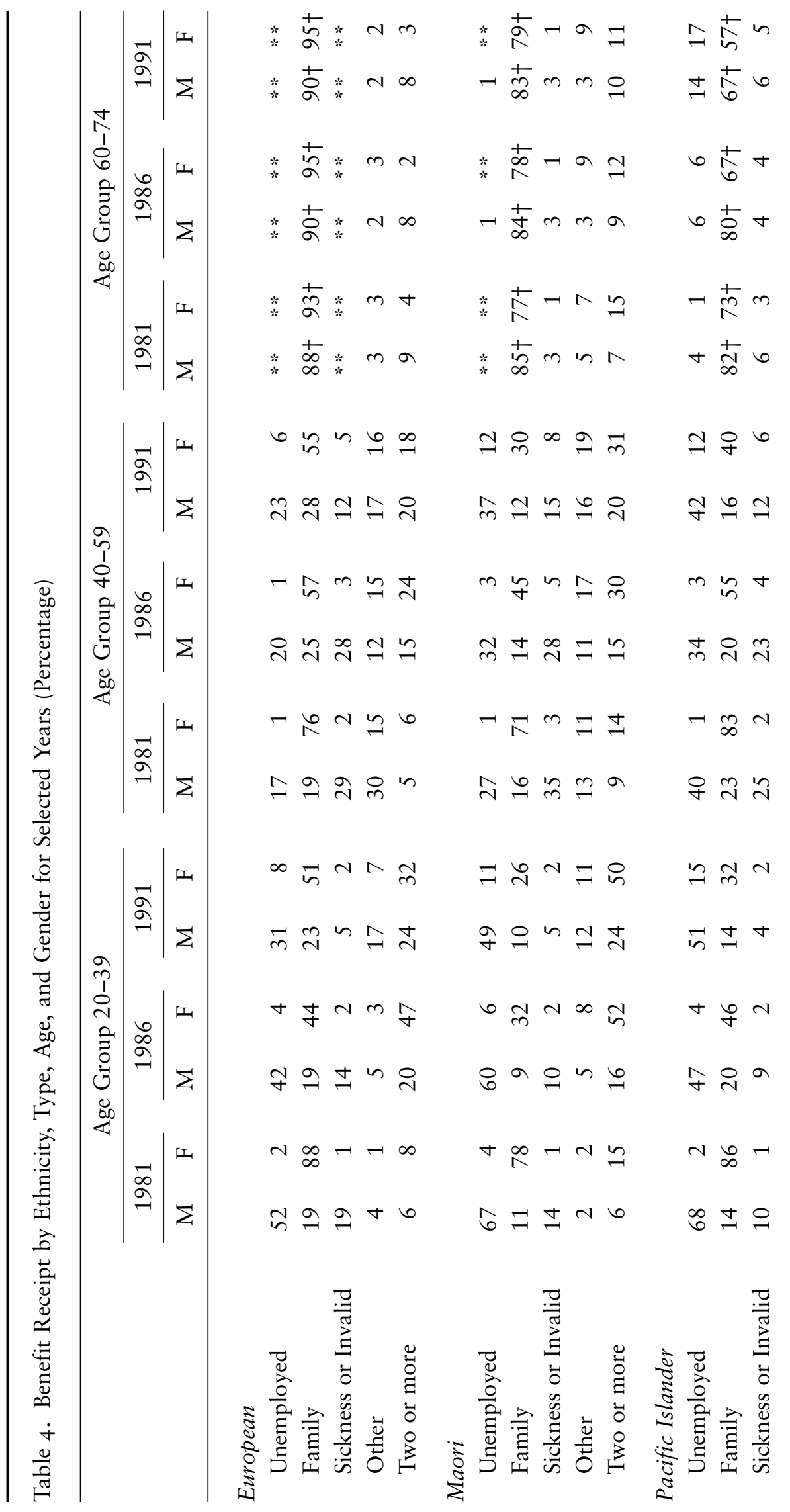




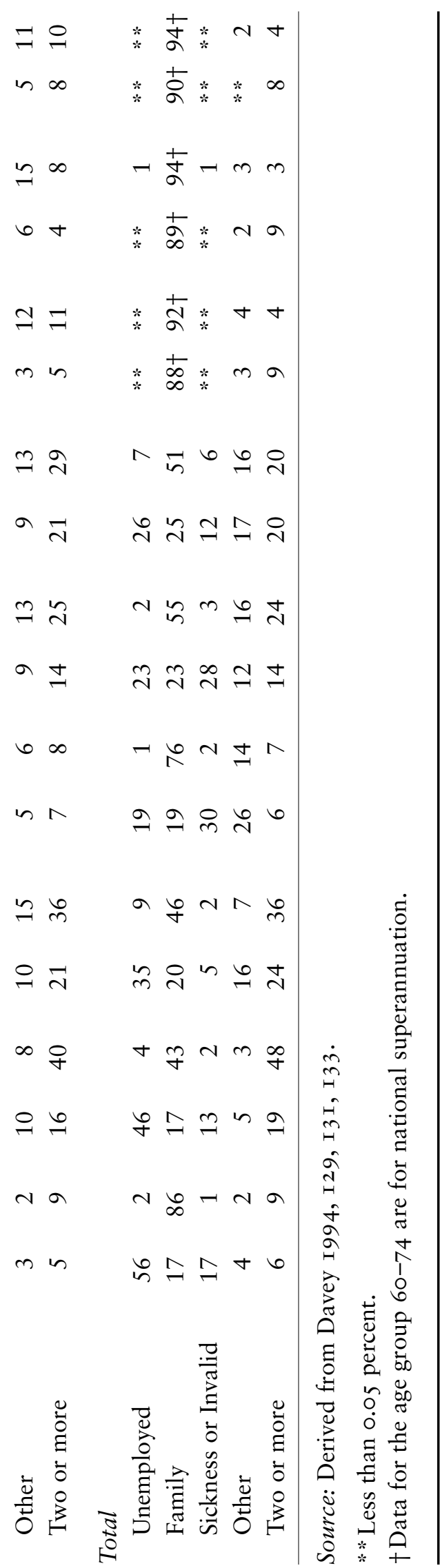


resenting the West Auckland community and that the Crown, by reducing funding to the trust, had failed to recognize both the representative and the trust status of the Waipareira Trust as a treaty partner.

The urban Maori authorities also seek social justice and compensation on behalf of "detribalized" Maori and have filed "pantribal" court appeals challenging proposals to redistribute treaty settlement assets via iwi mechanisms. Alleging that most Maori are urban, some authority leaders contend that many urban Maori are detribalized and that detribalization militates against social justice and the fair and equitable distribution of treaty settlement assets among all persons of Maori descent. John Tamihere and June Jackson, chief executive of MUMA, maintain that many urban Maori do not engage in iwi activities and do not embrace Maori tribal customs via the marae. Both officers also assert that detribalization constrains many urban Maori from obtaining redress and social justice for the legacy of dispossession and marginalization caused by the Crown's abrogation of Article III treaty rights (Jackson I994; Tamihere 1994).

Yet leaders of Maori tribal organizations vigorously refute these allegations and arguments, challenging both the extent of detribalization and the logic of distributing tribally held private settlement assets to persons who are not affiliated with the tribe. Settlement assets provide redress to descendants of Maori wrongfully harmed by the Crown's abrogation of Article II treaty rights and, thereby, offer tribal collectives the promise of substantial economic development benefit as well as sovereignty over sacred sites. Treaty settlement is an effective and important group mechanism for providing social justice and redress. Only Maori who are affiliated with the particular iwi named in specific treaty settlements are entitled to share in settlement assets, because assets derive from the unjust confiscation of private tribal assets. In order to share the benefits of treaty settlements, individual Maori—urban and rural—must provide proof of tribal affiliation.

Foremost, tribally affiliated Maori maintain that if a person of Maori descent is truly detribalized (unable, unwilling, or otherwise too alienated to demonstrate tribal affiliation), then by definition, that person cannot share in the benefits of treaty settlements negotiated by the tribe as redress for illegal confiscation of tribally held private assets. Leaders of tribal entities also contest estimates of the actual numbers of Maori who are said to be detribalized and the extent to which detribalization occurs. Rather, many Maori who are active in tribal matters contend that the great majority of Maori actually are affiliated with iwi, Moreover, this 
view is substantiated by recent census data. According to the census, in I99I approximately 7I percent of Maori identified affiliation with at least one tribe, while in 1996 the number increased to 74 percent. Opposition to the detribalization notion is perhaps best articulated in a recent communication from a former member of the Waitangi Tribunal.

There is dispute, much of it quite artificial, about just how many "urban Maori" are in fact "unaffiliated" or "do not know" their tribal connection, or are truly "unable" to find out. Available statistics and factual evidence indicates a quite small number. . . . No doubt there will be at least a few who know they are Maori but do not know their proper tribal connections. . . . there is a duty on the individual to make an effort to contact their tribal authority, as well as a duty on the Tribe to seek out its members and to assist them, wherever they are living. . . . The majority of people who are urban definitely do know their tribal rights, and how to go about tribal business of all kinds even if they are in the city.

Also it must be recognized that most Maori are tribal, and that "tribal" describes a huge range of things [from] intense involvement in tribal life and traditional activities . . . to once a week, monthly, maybe only at the annual tribal hui [meeting] . . . by attending a funeral, wedding or family reunion, or ... a trip home from Australia or London. Even those who haven't been home for years still know their tribal connections and carry that with them everywhere. Of course there are many problems with this, especially for the children, but Maori people, and their tribal organizations, are acutely aware of them all, and do what they can with limited resources to keep alive their culture and identity. . . . If truly detribalized, you cannot participate in a treaty settlement, because that belongs to a tribe. (Former tribunal member, personal communication, I I Nov I997)

Many proponents of the detribalization thesis and pantribal or nontribal strategies for distributing treaty assets overlook the critical distinction between the redress due Maori collectives for the wrongful and illegal confiscation by the state of collectively held private assets under Article II and the redress due individual Maori for the deprivations-dispossession and marginalization-caused by breached citizenship rights under Article III. Exactly what are the government's obligations in providing redress and social justice to Maori as individuals (or households) for breached treaty rights under Article III, as benefits and privileges of citizenship? According to the former member of the tribunal,

Treaty settlements actually involve the return to Maori people collectively of assets, and thence income, assets that always belonged to them but were 
wrongly taken away or withheld by the State hitherto because of breaches of the Treaty, and usually of outright illegality under ordinary Law as well. This important distinction needs constant assertion, because many people fail to notice that "Treaty settlement assets, or income" represent private property, albeit communally held, and not any kind of State or public funds, and therefore [are] not expected to pay for costs of State programs or for the duties of the State towards its citizens under welfare legislation or the like. This is the most obvious flaw in the contentions of Waipareira and mUMA. Government in the past has often in fact diverted the property of others (Maori citizens and their tribal collectives) to serve Governments' own purposes, usually against the interests and desires of the true owners. It is a modern tragedy that we now have Maori individuals trying to do the same thing.

Providing social justice and equity is the responsibility of Government, not the tribal authorities. If welfare organizations, such as the UMAs, need further resources, funds ought to be provided by Government, not taken from private or tribal collective estates. This of course does not rule out the possibility, perhaps even the likelihood, that iwi collectives might very well decide to make donations in that direction of their own free will, or that iwi might decide to contract some UMA, or other city agencies to provide certain services to their membership in a city area. Major difficulties arise from attempts by certain Maori individuals to take away tribal assets by political or legal force, and then apply the fruits to various government programs that they happen to be in charge of administering. (Former tribunal member, personal communication, I I Nov 1997)

\section{Pantribal Challenges to the Allocation and Distribution of Treaty Settlement Assets}

The problem of detribalization has rekindled passionate debate and conflict within Maoridom over the allocation and distribution of treaty settlement assets. Although some New Zealanders allege that the dispute is being waged by a few Maori individuals seeking to appropriate treaty settlement assets to fund their own organizations, the path to asset distribution has been impeded by legal wrangling and litigation since settlement of the fisheries claims in 1992.

For example, the ongoing battle over allocating and distributing fisheries settlement assets involves assets currently estimated at NZ\$700 million. In September 1992, the Treaty of Waitangi Fisheries Commission was charged to allocate pre-settlement assets of NZ\$200 million to Maori people, and subsequently litigation ensued over whether assets should be 
divided on the basis of tribal population or coastline. Leaders of urban Maori authorities maintain that "many Maori now live not in the old tribal areas with which iwi are associated, but in town; and it has been claimed on behalf of these 'urban Maori' that allocation to iwi would not provide for them any or any proper share of the benefit to be distributed under the allocation by the Commission of pre-settlement assets to iwi" (CPC I997, 4).

Therefore, leaders undertook a series of legal actions to enable Maori to transfer their individual share of iwi settlement assets to the urban organizations that deliver services to them. In March I995, the Manukau Urban Management Authority and the Waipareira Trust initiated a High Court challenge to the Fisheries Commission's proposals for distributing settlement assets to iwi. In July 1995, the tribes supporting either of the coastline or population models of allocation agreed to work together and formed the Treaty Tribes Coalition. In August 1995, the High Court decided that the Waitangi Tribunal could not consider the allocation of fisheries assets. In April 1996 the Appeal Court of New Zealand not only upheld the High Court decision that the Waitangi Tribunal could not consider the allocation of fisheries assets, but further ruled that urban Maori have a right to share in the fisheries settlement assets. In June 1996, the Treaty Tribes Coalition, Muriwhenua, Tainui, and Ngati Porou appealed the August decision to the Privy Council.

In the Muriwhenua appeal, the judgment rendered by Lord Robin Cooke of Thorndon in the Court of Appeal held "the most important point to be made at the outset of our present judgement is that the deed of settlement was conceived as a pan-Maori settlement of fisheries claims. It was not for the benefit of selected groups of Maori only" (CPC I997, I 5-I6). The appeal decision turned on the use and meaning of the Maori word iwi. The term, as introduced in the 1975 Treaty of Waitangi Act, is said to refer to "the Queen's subjects already living on the land and others yet to come." Iwi is defined as "nation people" (not tribe) and the word $h a p u$ is used to refer to tribe or subtribe. Judge Cooke ruled that the "Deed of Settlement of all the commercial fishing rights and interests of Maori is ultimately for the benefit of all Maori" (NZCA I996, 27).

The central problem here is one of apportionment. In the initial deed of settlement, the Treaty of Waitangi Fisheries Commission was established in 1992 to facilitate development of Maori fisheries enterprises and to manage fisheries assets. In addition to ro percent of the national fishing quota ("presettlement assets"), the commission acquired a further 26 
percent, through a 50 percent shareholding in Sealord Products Limited and the rights to 20 percent of all quota for any further species of fish bought within the quota management system, as well as other cash assets held by the commission (post-settlement assets). The fundamental question is how to apply both categories of assets for the benefit of all Maori. This issue arises because the Fisheries Commission proposed to redistribute assets based on coastline, mana whenua, mana moana (authority over the land carries authority over the sea). Thereby, one model of allocation would give a coastal tribe(s) all the quota for the inshore fishery adjacent to its coast and 50 percent of the corresponding deep-water quota, the remainder to be divided among tribes according to population. According to Judge Cooke, this model would unfairly advantage a tribe such as Ngai Tahu because of the very long South Island coastline, while it would unfairly disadvantage inland tribes or tribes with less coastline, such as Muriwhenua (NZCA I996, 27).

In the April 1996 decision, the court held that "the annual lease rounds have resulted in Ngai Tahu receiving the lion's share of settlement benefits hitherto" (NZCA). Judge Cooke ruled that "iwi refers, as we have said, to the people of tribes; and this must include those entitled to be members although their specific tribal affiliation may not have been and even cannot be established. They are among those entitled to benefit from panMaori settlement. Natural justice requires that as far as reasonably practicable they be consulted by the Commission" (NZCA I996, 29). The Fisheries Commission was further charged to formulate a model that apportioned fisheries assets to benefit all Maori, tribally affiliated and nonaffiliated. The central issue turned on the definition and meaning of $i w i$ and on the question of whether urban Maori authorities were iwi. Although there was extensive debate on this question, on I6 January 1997, the judgment of the Lords of the Privy Council "pre-empted the function of the Commission on the point of [a] separately administered provision for urban Maori." The Privy Council declined to interfere but chose to "advise Her Majesty that appeals on this point ought to be allowed ... and the matter remitted to the trial judge for further hearing" (CPC I997, I2).

Thus the I6 January 1997 judgment of the Privy Council delivered by Lord Goff of Chieveley overturned the Appeal Court ruling and sent the issue back to the High Court. On 6 July 1998, the Waitangi Tribunal issued its findings that "non-tribal Maori groups may be entitled to special consideration in terms of the Treaty. . . they should not be treated 


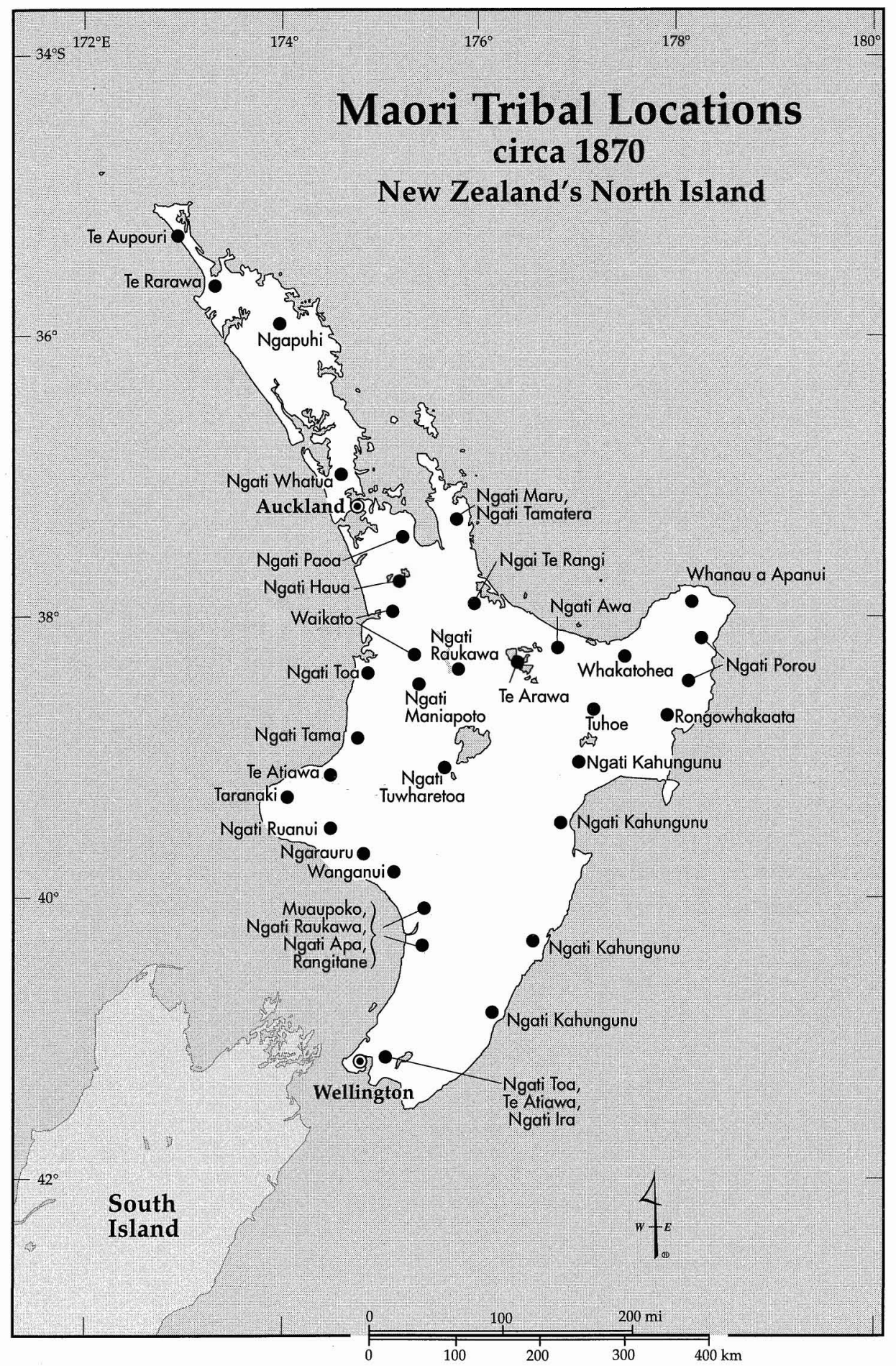

Map I. After Oliver I99I. 


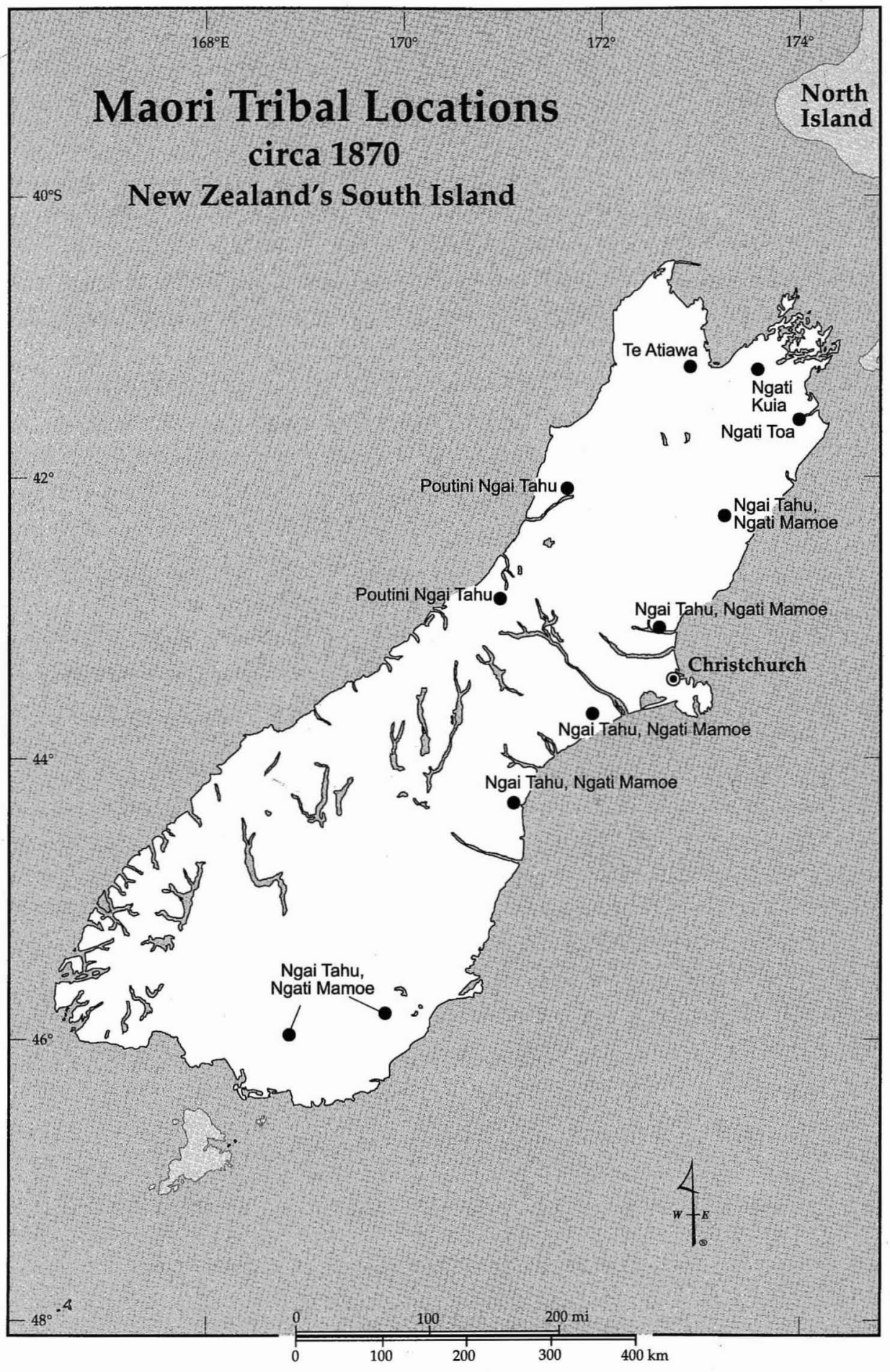

Map 2. After Oliver I99I. 
simply as another interest group under the Treaty's equal citizenship provisions" (Waitangi Tribunal I998b). In addition, the tribunal maintained that the treaty is a "living document" directed to Maori interests generally, not merely as classes of property interests, and is not limited to tribes but applies to a variety of situations. However, the Crown counsel's argument held sway, "that rangatiratanga is guaranteed protection only in Article II of the Treaty, and it only applied in respect of the control of properties by $i w i$ and $h a p u$. . . since Waipareira was not a traditional tribe or iwi with customary lands and fisheries, it could not exercise rangatiratanga, and its membership had no rights other than citizenship rights" (Waitangi Tribunal I998b). On 4 August I 998 Justice Paterson of the High Court in Auckland ruled in favor of "defining iwi as being a traditional Maori tribe and supported traditional tribes distributing fisheries assets" (Wellwood I998, I). Justice Paterson also ruled that "the Waitangi Fisheries Commission had a duty to ensure that any scheme allocating fisheries assets had to cater adequately for all beneficiaries of the settlement" (Wellwood I998, I). Thus the pendulum of social justice continues to oscillate between reparative and distributive instruments.

\section{CONCLUSION}

From the I970s to the I990s, the government used two strategies to address Maori grievances: targeted social policy and reparative treaty settlement. New Zealand policymakers committed substantial resources and good faith to the improvement of Maori economic and social well-being by means of targeted programs via the Department of Maori Affairs and by providing redress for breaches of the Treaty of Waitangi via the Waitangi Tribunal. Before targeted social policies could take hold and be evaluated, however, macroeconomic exigencies collided with social justice. The government devolved targeted programs, cut social welfare, and mainstreamed Maori into universal programs irrespective of lingering effects of dispossession and marginalization.

Increasingly, many scholars, analysts, and politicians acknowledge that New Zealand's decade of budgetary and social policy reforms not only exacerbated poverty among the least advantaged but also rendered New Zealand a far less egalitarian society than it had been (Kelsey I995; Martin 1995; Rowntree Foundation I995; Mowbray and Dayal 1994). Unlike those in the United States, problems of poverty in New Zealand generally were not deemed intractable, racial, or ethnic. Although a relatively small 
number of better educated (3.4 percent in I991; 7.7 percent in 1996) and tribally affiliated Maori prospered over the decade, the number of impoverished Maori also increased significantly, by I I percent.

Furthermore, expansion of the top and bottom income quintiles has sharpened class differences between Maori elites and the working class and revealed a Maoridom that is neither monolithic nor homogeneous. Rather, class differences over aspirations, goals, and means for Maori people are at the center of discourse on detribalization, legal challenges over distribution of treaty settlement assets, and debate over the government's pursuit of pantribal versus iwi-based approaches to Maori policy. In March I995, the Labour party soundly criticized the effects of the reforms on the poor. Opposition leader Helen Clark repudiated the public sector reforms and characterized them as "the Americanization of New Zealand" because they demonstrated the National government's "preference for a booming economy at the expense of social justice with the attendant creation of a permanent underclass without any hope of getting out" (Clark I995).

Thus far, treaty settlements have neither improved economic and social well-being among the majority of Maori households nor offset the impact of the reforms. In fact, very few deeds of settlement have reached the asset disbursement stage. Treaty settlement assets were neither conceived nor intended for distribution as trickle-down social welfare. Rather, treaty settlements render reparative justice to tribes, whereas equity and equality require distributive justice by means of positive discrimination. Treaty settlement assets are distributed to Maori tribal collectives-iwi and hapu - and managed by tribal trust boards, generally, as commercial ventures and investment portfolios. Limited benefits are provided directly to individual Maori and then principally as educational grants and tertiary and university scholarships to Maori students who acknowledge iwi affiliation and participate in iwi activities. Although tribal trust boards provide limited social services, the objective is not to supplant government responsibility.

In conclusion, the debate over detribalization and asset redistribution is rooted largely in confusion over collective and individual redress for breaches of Articles II and III of the Treaty amid the declining economic and social well-being of Maori households. Furthermore, the debate leaves unresolved the two questions, raised but left wanting during devolution and mainstreaming, that remain at the center of current ligation over allocation and distribution of treaty settlement assets today. Is the treaty between the Crown and Maori people as a whole or is it between 
the Crown and local subtribes and extended familial groupings-te runanga iwi? What are the government's obligations in rendering redress and social justice to Maori as individuals (or households) for breached treaty rights under Article III, as benefits and privileges of citizenship? The issues raised by the detribalization debate and pantribal challenges, as well as the redistributive problems they seek to resolve, demonstrate that the contemporary situation of Maori is not exclusively a problem of abrogated treaty rights and sovereignty. Increasing inequality between Maori and Europeans is also exacerbated by deindustrialization, economic restructuring, and public sector reforms, as well as the legacy of dispossession and marginalization. Therefore, social justice also requires distributive mechanisms targeted to all Maori people, tribally affiliated and nonaffiliated, to provide redress for breaches of Article III, in addition to reparative mechanisms to settle breaches of Article II.

This STUdy WAS FACILITATED by generous support from the United States Fulbright Program, the Governmental Studies Division of the Brookings Institution, Howard University's Center for Urban Progress, and the Center for the Study of Urban Inequality in the Harris Graduate School of Public Policy Studies at the University of Chicago. I am enormously indebted to many New Zealand entities and their staffs, in particular the New Zealand-United States Educational Foundation, the Alexander Turnbull Library in Wellington, the Ministry of Maori Development, the Dictionary of New Zealand Biography, the Maori Statistics Forum, and Statistics New Zealand.

\section{Notes}

I Pakeha is the Maori term for whites or Europeans. Some whites regard this term as pejorative, while others use it as an acceptable synonym. In official statistics and reports European is used to describe white settlers and immigrants and their descendants. Consistent with New Zealand journalism conventions, I have used Pakeha and European interchangeably throughout the text and European in descriptive statistics. English translations of Maori words are from Harawira and Karetu (I994).

2 The 1863 New Zealand Settlement Act was the first major legislation that sanctioned compulsory land confiscation. As punishment for Maori fighting against European settlement colonization in the I860s, approximately 3.5 million acres were taken from Maori as a prize of war. From I905 onward Maori Land Boards were authorized to compulsorily acquire land declared not required 
for actual occupation by Maori. Between I 865 and I 899 , approximately I I million acres of Maori land were transferred to European hands under the land laws, leaving approximately 8 million acres in Maori freehold ownership. Between 1900 and 1930 another 4.5 million acres of Maori land were alienated and a further 3 million acres were leased. In a I 920 survey, it was estimated that 400,000 acres were occupied by Maori and 800,000 acres were available for Maori use (Ward 1997). Although government decision makers slowed the pace of land confiscations by enacting the 1929 Native Land Amendment Act and Native Land Claims Act, these acts were reversed by the 1953 Maori Affairs Act. Under that act, any interested person could submit information to the Maori Land Court claiming a particular parcel of land was unproductive (or had noxious weeds or unpaid rates). The act also empowered Maori trustees, who could alienate Maori-held lands by leasing or selling them as they saw fit. The I953 Town and Country Planning Act restricted the use of Maori-held lands via zoning laws.

3 Nga Tamatoa defined a system of "ethnic nationalism" by ascribing a "black" identity and consciousness drawn from the writings of Franz Fannon, Charles Hamilton, and Stokeley Carmichael. This new identity proclaimed the unique political capacity of Maori culture as the basis for self-determination. Maori ethnicity emerged as the key weapon to counter the prevailing ideologies and resolve grievances over the loss of language, land, and power (Greenland I99I, 9I).

4 The operative meaning of Maori sovereignty remains an unsettled question within both Maoridom and New Zealand society. For comprehensive discussion see Awatere (I984); Cox (I993); McHugh (I99I); Sharp (I99I).

5 The power to report on the consistency of proposed legislation with treaty provisions has never been exercised, and can only be invoked by reference from Parliament itself. So far this has never been done.

6 Only an approximate count is available at this time. Increasingly, related main and smaller ancillary treaty claims are amalgamated in order to facilitate adjudication. For example, the Ngai Tahu claim included 8 related major claims and II7 small ancillary claims.

7 The South Island claims include the Otakou, Banks Peninsula, Murihiku, North Canterbury, Rakiura, and Arahura purchases; perpetual leases of Ngai Tahu reserves; and mahinga kai (food resources).

8 Several distinct Asian ethnic groups are resident in New Zealand. Many immigrated from Korea, Japan, Hong Kong, Malaysia, South Africa, and Fiji in the I980s; some are refugees from Cambodia, Vietnam, and Thailand who immigrated in the I970s; and others are second and third generation Chinese. Census data on the "Asian" populations are not recorded consistently over time. In some years the data are pooled with "all other" groups, and in other years they are disaggregated into Chinese and Indian. Also, approximately 4.4 percent of the population did not specify their ethnicity in the 1996 census. 
9 Data on labor force participation, occupations, and unemployment are not disaggregated for each ethnic group over the entire period of study. Until I986 data are disaggregated only as Maori and European. Data for Pacific Islanders and Asians are enumerated from I987 onward.

Io Unlike the United States, where the educational premium is high and allegedly contributes to labor market segmentation, in New Zealand the returns to higher education remain small across all groups until I986 (Lashley I999). According to New Zealand historians Claudia Orange and Willima Oliver, the working class majority did not define education as indispensable to achieving a good and comfortable quality of life. New Zealanders deemed formal education neither instrumental to wealth accumulation nor economic and social well-being, and the premium paid for higher education was small until the mid-I980s. Work tended to be compensated equally, given stringent union regulation enforced by the social democratic compact between the government, employers, and workers (Oliver I994; Orange I994). In a study of Maori occupational segregation, I956 to I98 I, Brosnan redefined the occupational code (from two to four digits, with "manual workers" partitioned as unskilled and skilled) and found the ratio of unskilled to skilled manual workers was 3:I for Maori and 0.9:I for Europeans (I986). Maori also had lower median incomes, given concentration in unskilled work, but there was no evidence of either a dual labor market (in which Maori earn lower wages than Europeans in the same skill code for the same work) or labor market segmentation.

I I Brian Easton also found some evidence of labor market segmentation emerging in his analysis of 1993 household labor force data on Maori employment (1994). In a recent study of family incomes in I98I and I99I, Barry Martin found "restructuring altered income relativities between family types and between ethnic groups. The relative position of male sole parents and Maori and Pacific Islanders has deteriorated ... the freeing up of pay relativities, and the rapid rise of unemployment in the late I980s have not struck families equally" (I995).

I 2 Urban Maori authorities are members of the Federation of Maori Authorities, a network of Maori organizations that foster and promote development, management, and economic advancement for Maori. These include tribal trust boards, land trusts, economic authorities, and other entities.

\section{References}

Awatere, Donna

I984 Maori Sovereignty. Auckland: Broadstreet Publications.

Brosnan, Peter

I986 Maori Occupational Segregation. Industrial Relations Centre Working Paper 2. Wellington: Victoria University of Wellington. 
Butterworth, Graham, and Hepora Young I990 Maori Affairs. Wellington: Government Printing Office.

Clark, Helen I995 Interview on Radio New Zealand, Wellington. 26 March.

Cox, Lindsay I993 Kotahitanga. Auckland: Oxford University Press.

CPC, Committee of the Privy Council I997 Appeals 68, 69, and 70. Judgement, I 6 January.

Davey, Judith

I994 Who Benefits? The Receipt of Income Support by Age, Gender, and Ethnicity. Social Policy Journal of New Zealand 2 (July): I I 3-I 42.

Davies, Lisa, and Natalie Jackson

1993 Women's Labour Force Participation in New Zealand: The Past 100 Years. Wellington: Social Policy Agency.

Durie, Edward I996 A Judge's Eye View of the Treaty of Waitangi Tribunal. Paper presented at the Indigenous Peoples Conference, Vancouver, BC. 20-22 March.

Easton, Brian

I994 The Maori in the Labour Force. Wellington: Ministry of Maori Development.

Gardiner, Wira

I994 Setting the Scene. In Proceedings of the Maori Health Decade Hui, 54-62. Wellington: Ministry of Maori Development.

Gardner, James

I995 Ministers to Get Guards for Huis. Dominion (Wellington), I3 February, I-2.

Goodall, Maarire

I996 Interview at Aoraki Press, Wellington, 26 January.

I997 Interview at Aoraki Press, Wellington, 25 November.

Graham, Douglas

I994 Interviewed as Minister of Justice and Minister in Charge of Treaty of Waitangi Negotiations. Wellington, 23 November.

Greenland, Hauraki

I99I Ethnicity as Ideology. In Nga Take: Ethnic Relations and Racism in Aotearoa/New Zealand, edited by Paul Spoonley, David Pearson, and Cluny Macpherson, 86-IO2. Palmerston North: Dunmore Press.

Gurr, Ted, and James Scarritt I989 Minorities at Risk: Global Survey. Human Rights Quarterly II: $375-405$.

Harawira, K T, and Timoti Karetu

I994 Teach Yourself Maori. Auckland: Reed. 
Hardy, Jean

196I Interpretation of Plurilingual Treaties by International Courts and Tribunals. British Yearbook of International Law 37:72-98.

Hazelhurst, Kayleen

I993 Political Expression and Ethnicity. Westport, Ст: Praeger.

Henare, Manuka

I 994 Interviewed as Head, Maori Studies, Victoria University of Wellington, 9 September.

High Court of New Zealand I996 Judgement, 30 April.

Hunn, J K

I960 Report on the Department of Maori Affairs. Wellington: Government Printer.

ITA, Iwi Transition Agency

I990 Report of the Iwi Transition Agency Working Group on the Runanga Iwi Bill, Local Government Amendment Bill (No. 8) and the Resource Management Bill. 30 January. Wellington: Government Printer.

Jackson, June

I994 Interviewed as chief executive officer of Manukau Urban Management Authority, 2 November.

Jackson, Syd I994 Interviewed as activist. Auckland, 4 November.

Jackson, Te Moana Nui A Kiwa

I994 Interviewed at Maori Legal Services, Wellington, 24 November.

Kawharu, I H

I989 Maori and Pakeha Perspectives of the Treaty of Waitangi. Auckland: Oxford University Press.

Kelsey, Jane

1995 The New Zealand Experiment. Auckland: Auckland University Press.

Kingi, Pauline

I984 The Treaty of Waitangi. Master of Laws thesis, Harvard University.

I994 Interviewed as regional director of Te Puni Kokiri. Auckland, I I March.

Lashley, Marilyn

I999 Balanced Budgets Unbalanced Costs: The Impact of the New Zealand Experiment on Maori Social and Economic Well-Being. International Policy Review 8 (Spring): 49-63.

MacDonald, Robert

I990 The Maori of Aotearoa-New Zealand. London: Minority Rights Group.

Mahuta, Robert

I978 Mabuta Commission on Devolution. Wellington: Department of Maori Affairs. 
Maori Law Review. I996 Urban Maori and the Fisheries Settlement. May, 4-7.

I997a Other Courts and Tribunals. December I996-January I997, 2-4.

1997b Waitangi Tribunal. March, 2-6.

Martin, Barry

I995 The New Zealand Family and Economic Restructuring in the I980s. Population Studies Centre Discussion Papers, May. Hamilton: University of Waikato.

McHugh, Paul

I99I Maori Magna Carta. Auckland: Oxford University Press.

McLeay, E M

I99I Two Steps Forward, Two Steps Back: Maori Devolution, Maori Advisory and Maori Representation. Political Science 43 (I): 32-46.

Metge, Joan

I964 A New Maori Migration: Rural and Urban Relations in Northern New Zealand. Melbourne: Athlone Press.

I976 The Maoris of New Zealand: Rautahi. London: Routledge \& Kegan Paul.

Miller, David

I99I Justice. In Blackwell Encyclopedia of Political Thought, edited by David Miller, J Coleman, W Connolly, and A Ryan, 260-263. Oxford: Blackwell.

Mowbray, Mary

I993 Incomes Monitoring Report. Wellington: Social Policy Agency.

Mowbray, Mary, and Neela Dayal

I 994 The Fall and Rise of Household Incomes. Social Policy Journal of New Zealand 2 (July): I I4-I 22.

NZCA, Zealand Court of Appeal

I996 Judgment of 30 April.

NZDsw, New Zealand Department of Social Welfare

I986 Puao-te-Atatu/Day Break. Wellington: Department of Social Welfare.

I993 Social Environment Scan. Wellington: Department of Social Welfare.

I994 Statistical Information Report. Wellington: Department of Social Welfare.

nZmma, New Zealand Ministry of Maori Affairs

I984 Maori Economic Development Summit Conference. Wellington: Te Puni Kokere.

NZMmd, New Zealand Ministry of Maori Development

I986 Te Urupare Rangapu (Partnership Agreement). Wellington: Government Printer.

I994 Summary of Mainstreaming. Wellington: Government Printer.

1997 Review of the Ministry of Education Service Delivery to Maori. Wellington: Government Printer. 
NZMPG, New Zealand Ministerial Planning Group

I99 I Ka Awatea. Wellington: Ministerial Planning Group.

Nzots, Office of Treaty Settlement

I995 Crown Proposals for the Settlement of Treaty of Waitangi Claims. Wellington: Department of Justice.

I996 Briefing to Incoming Government. Wellington: Office of Treaty Settlement.

NTNG, Ngai Tahu Negotiating Group

I997 Crown Settlement Offer. Christchurch: Ngai Tahu Publications.

Oliver, William

I99I Oxford History of New Zealand. Oxford: Oxford University Press.

I 994 Interview with former editor of the Dictionary of New Zealand Biography. Wellington, I 6 March.

Orange, Claudia

I994 Interview with editor of the Dictionary of New Zealand Biography. Wellington, I 6 March.

Ralston, Caroline

I993 Maori Women and the Politics of Tradition: What Roles and Power Did, Do, and Should Maori Women Exercise? The Contemporary Pacific 5:23-44.

Rowntree Foundation

I995 Inquiry into Income and Wealth. York, UK: Rowntree Foundation.

Royal Commission of Inquiry

I972 Social Security in New Zealand. Wellington: Government Printer.

Royal Commission on Social Policy

I988 Report of Royal Commission on Social Policy. April. Wellington: Government Printer.

RRC, Race Relations Conciliator

I982 Race against Time. Wellington: Human Rights Commission.

I987 Towards an Equitable Society: Affirmative Action. Auckland: Race Relations Office.

Schwimmer, Erik G

I968 The Maori People in the Nineteen Sixties. Auckland: Blackwood \& Paul.

Sharp, Andrew

I99I Justice and the Maori. Auckland: Oxford University Press.

1992 The Problem of Maori Affairs. In The Fourth Labour Government: Politics and Policy in New Zealand, second edition, edited by Martin Holland and Jonathan Boston, 25 I-269. Auckland: Oxford University Press.

snz, Statistics New Zealand

I99I Household Expenditure and Income Survey. Wellington: Statistics New Zealand. 
I996a Census of Population and Dwellings. Wellington: Statistics New Zealand.

I996b Census of Population and Dwellings: 1976, I981, 1986, I991 and 1996. Special release. Wellington: Statistics New Zealand.

I998a Highlights: Employment. Wellington: Statistics New Zealand.

I998b Household Economic Survey. Wellington: Statistics New Zealand.

I998c Household Labour Force Survey. Wellington: Statistics New Zealand. SPA, Social Policy Agency

I993 Social Environment Scan: Brief for the Minister of Social Welfare. Wellington: Department of Social Welfare.

Tamihere, John

I994 Interview with chief executive officer, Waipareira Trust. Auckland, 5 December.

Te Hemara, Hana

I994 Interview with former member of Nga Tamatoa. Auckland, 2 November.

Te Ua, Henare

I 994 Interview. Te Reo O Aotearoa. Auckland, 3 November.

Tapsell, Peter

I998 Tapsell Wants New-look Dept. Press (Christchurch), 3 August.

Waitangi Tribunal

I992a Ngai Tahu Report. Wai 27. Waitangi Tribunal.

I992b Fisheries Settlement Report. Wai 307. Waitangi Tribunal.

I997 Muriwhenua Land Claim Report. Wai 45. Waitangi Tribunal.

r998a Turangi Township Claim Report. Waitangi Tribunal.

I998b Whanau O Waipareira Report. Wai 4I4. Waitangi Tribunal.

Walker, Ranginui

I995 Interview with head of Maori Studies Department, University of Auckland. Auckland, I I March.

Ward, Alan

I983 A Show of Justice. Auckland: Oxford University Press. Reprinted I99I.

I997 National Overview Report to the Waitangi Tribunal. Wellington: Waitangi Tribunal.

Wellwood, Elinore

I998 Maoris Split over \$70om Fish Decision, Press (Christchurch), 5 August.

\section{Abstract}

This study examines treaty settlement as a mechanism for providing social justice and incorporating Maori people into mainstream New Zealand society by improving economic and social well-being. Articles II and III of the Treaty of 
Waitangi (respectively, collectively held private assets and citizenship benefits and privileges) are described and discussed, along with settlement of claims of breached treaty rights, social policy targeted to Maori, and changes in economic and social well-being from 1976 to I 998 . The fundamental proposition is that all Maori are harmed by the legacy of dispossession and marginalization and, therefore, all Maori are entitled to social justice. The central question addresses the role of the state in providing redress to all indigenous New Zealanders, collectives and individuals, for breaches of both Article II and Article III treaty rights. However, urbanization and detribalization limit access to social justice, and the benefits of treaty settlements have yet to trickle down to individual Maori households. Changes in aggregate indicators of well-being indicate modest improvement in the first decade, and thereafter Maori people experience greater and increasing income inequality, unemployment, and poverty than other population subgroups. To explain these findings, the following questions are addressed: What is the relationship between detribalization and access to treaty settlement assets? What strategies should the government undertake to provide redress (to individual Maori as well as tribal collectives) for breaches of Article III treaty rights?

KEYWORDs: detribalization, Maori, New Zealand social policy, social justice, treaty settlement, Waitangi 